\title{
MANCHA DE ALTERNÁRIA DO FEIJOEIRO: ETIOLOGIA, RESISTÊNCIA DO HOSPEDEIRO E TRANSMISSÃO POR SEMENTES
}

\author{
MARIA HELOISA DUARTE DE MORAES \\ Engenheiro Agrônomo
}

Orientador: Prof. Dr. JOSÉ OTÁVIO M. MENTEN

Tese apresentada à Escola Superior
de Agricultura "Luiz de Queiroz",
Universidade de São Paulo, para
obtenção do título de Doutor em
Agronomia, Área de Concentração:
Fitopatologia.

PIRACICABA

Estado de São Paulo - Brasil

Março - 1996 
Dados Internacionais de catalogação na Publicação (CIP) DIVISÃo DE BIBLIOTECA E DOCUMENTAÇÃO - Campus "Luiz de Queiroz"/USP

Moraes, Maria Heloisa Duarte de Mancha de alternária do feijoeiro : etiologia, resistência do hospedeiro e transmissāo por sementes / Maria Heloisa Duarte de Moraes. - - Piracicaba, 1996. 97 p. : il.

Tese (doutorado) - Escola Superior de Agricultura Luiz de Queiroz, 1996. Bibliografia.

1. Feijāo 2. Mancha de alternária do feijāo 3. Resistência ao patógeno I. Título 


\section{MANCHA DE ALTERNÁRIA DO FEIJOEIRO: ETIOLOGIA, RESISTÊNCIA DO HOSPEDEIRO E TRANSMISSÃO POR SEMENTES}

MARIA HELOISA DUARTE DE MORAES

Aprovada em 31 de maio de 1996

Comissão julgadora:

Prof Dr. José Otávio Machado Menten

ESALQ/USP

Prof Dr. Hiroshi Kimati

Prof Dr. Tasso Leo Krugner

Dra. Margarida Fumiko Ito

Prof. Dr. Modesto Barreto

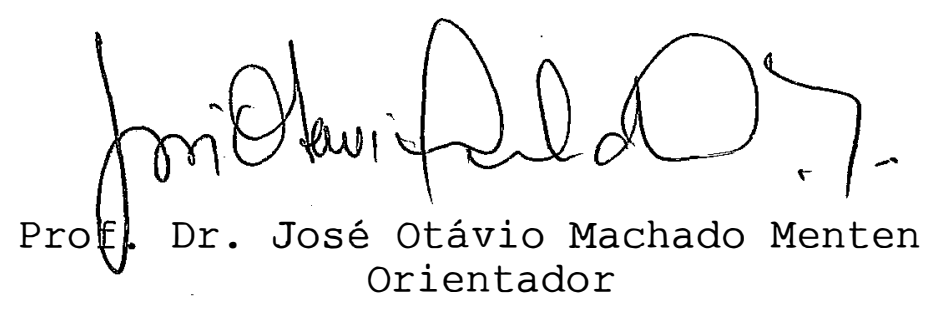




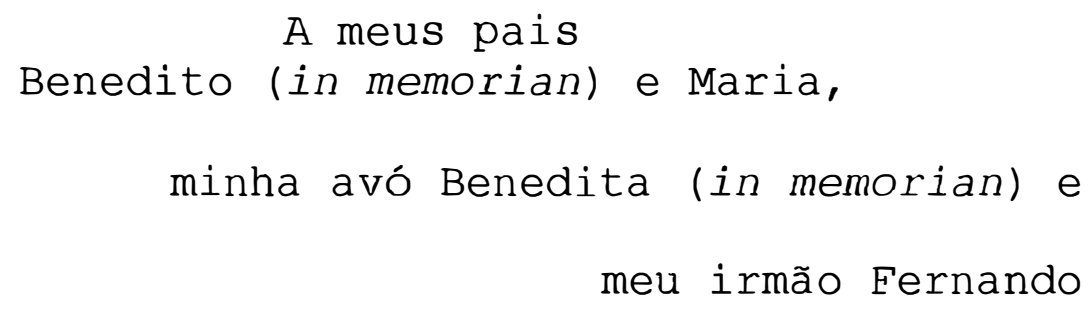

DEDICO 


\section{AGRADECIMENTOS}

- Ao Prof. Dr. José Otávio M. Menten pela orientação, incentivo e amizade.

- A Raquel F. Castellani pelo auxílio constante no Laboratório de Patologia de Sementes, principalmente neste último año.

- A Evelyn F. Koch e Pedro Silva pela amizade, apoio e estímulo.

- Aos colegas funcionários do Departamento de Fitopatologia pela amizade e compreensão.

- Ao. Prof. Dr. Tasso Leo Krugner pela elaboração do. summary •

- Ao Prof. Dr. Armando Bergamin Filho pelas sugestões e atenção dispensadas.

- Aos Prof. do Departamento de Fitopatologia pelos ensinamentos, colaboração e compreensão.

- Aos amigos do Laboratório de Tecnologia de Sementes do Depto. de Agricultura pelo incentivo constante.

- A Erna E. Bach, pesquisadora do Instituto Biológico de São Paulo, pela realização do trabalho de eletroforese. 
- A amiga Silvânia Helena Furlan de Oliveira (Instituto Biológicol pelos isolados de Alternaria.

- Ao Prof. Carlos Tadeu dos Santos Dias, da UNESP / Botucatu, pelo auxílio na realização das análises estatísticas.

- A Célia do Depto. de Horticultura pela atenção dispensada .

- A Kátia, Eliana e demais funcionários da Biblioteca Central pelo pronto atendimento.

- Aos amigos que aqui estão e aos que já passaram por aqui, não citando nomes para não incorrer em falhas de memória.

- A Flávio R. Lamanna, João Cazon e Lindaura Manoel, pelo auxílio no início dos trabalhos.

- Aos familiares, tias e primos, pelo apoio nas horas de cansaço e desânimo.

- À Fundação de Amparo à Pesquisa do Estado de São Paulo pelo apoio financeiro no início dos trabalhos.

- A todos aqueles que de alguma forma auxiliaram na realização deste trabalho. 
SUMÁRIO

Página

LISTA DI FIGURAS..................... v

LISTA DE TABELAS.................................

RESUMO ..............................

SUMMARY ................................

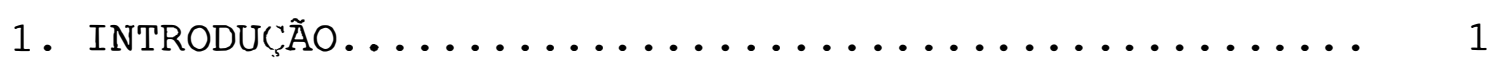

2. REVISÃo DE LiteRATURA...................... 3

2.1. Ocorrência da mancha de Alternária e danos causados em feijoeiro................. 4

2.2. Sintomatologia e etiologia da mancha de Alternária do feijoeiro.................. 5

2.3. Diferenciação das espécies de Alternaria..... 7

2.4. Resistência dos cultivares de feijoeiro a

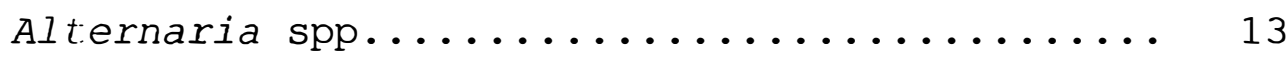

2.5. Trunsmissibilidade de Alternaria spp. através dais sementes de feijão................... 14

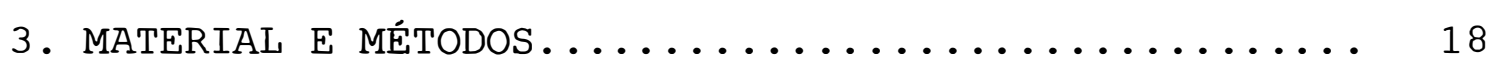

3.1. Isolamento de espécies de Alternaria do

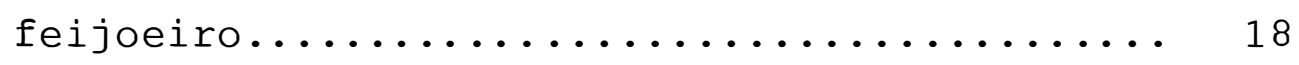

3.2. Preservação dos isolados de Alternaria spp.do 
Página

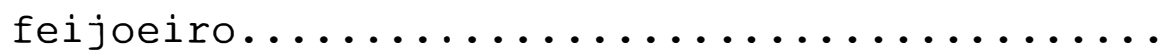

3.3. Caracterização morfológica dos isolados de Alternaria spp. do feijoeiro............ 20

3.4. Caracterização cultural dos isolados de

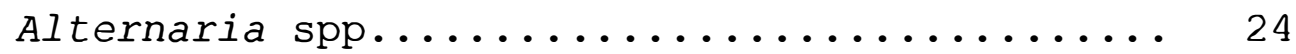

3.5. Caracterização eletroforética dos isolados

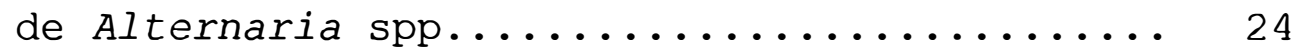

3.5.1. Desenvolvimento dos isolado em meio

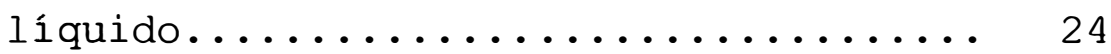

3.5.2. Extração de proteínas dos isolados.... 26 3.5.3. Determinação da concentração de proteínas nas amostras............. 26

3.5.4. Preparo do gel de poliacrilamida...... 27 3.5.5. Aplicação das amostras e corrida

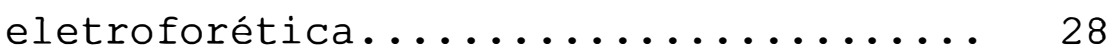

3.5.6. Coloração...................... 29

3.5.7. Preservação dos géis.............. 29

3.5.8. Análise do perfil eletroforético..... 30

3.6. Desenvolvimento de colônias de isolados de Alternaria spp. sob diferentes temperaturas... 30

3.7. Reação de cultivares de feijoeiro a diferentes isolados de Alternaria spp........ 
Página

3.7.1. Inoculação................... 31

3.7.2. Avaliação dos resultados........... 33

3.7.3. Quantificação da resistência........ 35

3.8. Transmissão de Alternaria spp. através das

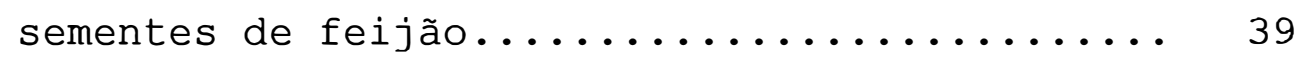

3.8.1. Inoculação artificial das sementes com os isolados de Alternaria spp........ 39

3.8.2. Testes em laboratório............ 40

3.8.3. Teste de emergência em casa-de-vegetação 41

4. RESULTAdOS E DISCUSSÃo .................... 43

4.1. Caracterização de isolados de Alternaria spp. do feijoeiro....................... 43

4.1.1. Caracterização morfológica......... 43

4.1.2. Caracterização cultural............ 55

4.1.3. Caracterização eletroforética dos isolados de Alternaria spp.......... 58

4.1.4. Desenvolvimento de colônias de isolados de Alternaria spp. sob diferentes

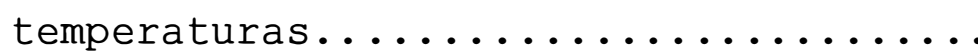

4.2. Reação de cultivares de feijoeiro a diferentes isolados de Alternaria spp..................68 4.2.1. Número de lesões por área foliar...... 68 
Página

4.2.2. Área foliar afetada.............. 70

4.3. Patogenicidade dos diferentes isolados de

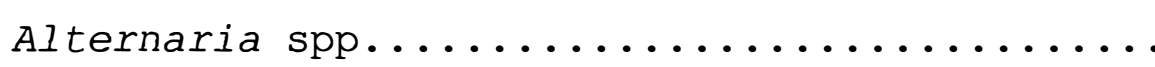

4.4. Transmissão de Alternaria spp. através das

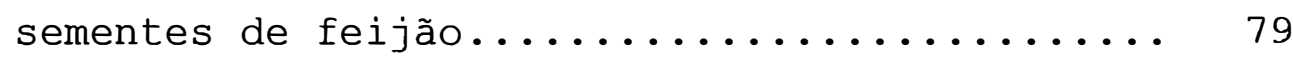

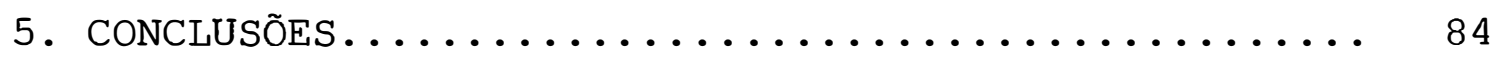

6. REFERÊNCIAS BIBLIOGRÁFICAS............... 86 


\section{LISTA DE FIGURAS}

Página

Figura 1 - Escala diagramática de severidade (porcentagem de área foliar afetada) da mancha de Alternária do feijoeiro (Godoy

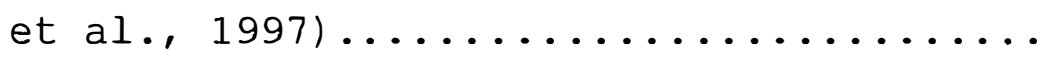

Figura 2 - Variação do comprimento ( $\mu \mathrm{m})$ do corpo do esporo" de isolados e espécies de

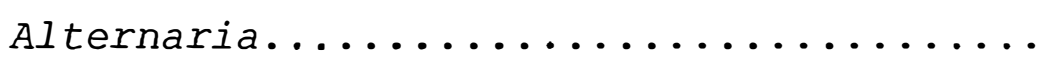

Figura 3 - Variação da largura $(\mu \mathrm{m})$ do corpo do esporo de isolados e espécies de

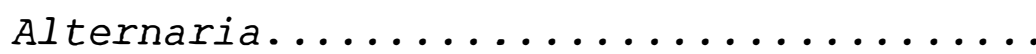

Figura 4 - Esporos dos isolados 1 e 3 da espécie Alternaria cichorii, observados em microscópio composto em aumento de 400x..

Figura 5 - Esporos dos isolados 4 e 5 da espécie Alternaria carthami, observados em microscópio composto em aumento de 400x..

.Figura 6 - Esporos dos isolados 7 e 8 da espécie Alternaria carthami, observados em 
Página

microscópio composto em aumento de 400x..

Figura 7 - Esporos dos isolados 9, 10 e 11 da espécie Alternaria carthami, observados em microscópio composto em aumento de 400x..

Figura 8 - Esporos dos isolados 2 e 6 da espécie Alternaria alternata, observados em microscópio composto em aumento de 400x..

Figura 9 - Diagrama dos perfis eletroforéticos de esterase e mobilidade relativa ( $\mathrm{Rm})$ de isolados de Alternaria cichorii, $A$.

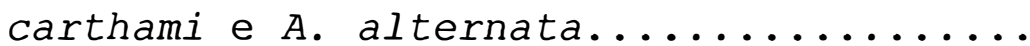

Figura 10- Diagrama dos perfis eletroforéticos de esterase e mobilidade relativa ( $\mathrm{Rm})$ de isolados de Alternaria brassicae, A. Cu-

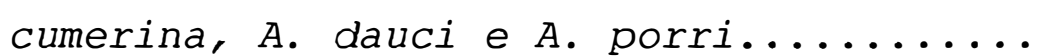

Figura 11- Diagrama densitométrico $(540 \mathrm{~nm})$ do padrão de esterase dos isolados de Alternaria cichorii, A. carthami e A.

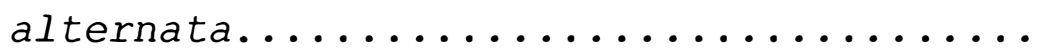

Figura 12- Diagrama densitométrico $(540 \mathrm{~nm})$ do padrão de esterase dos isolados de 
Alternaria brassicae, A. cucumerina, A.

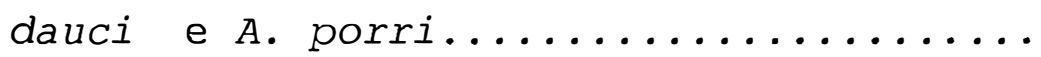

Figura 13- Quantificação de resistência horizontal e vertical incompleta em cultivares de feijoeiro para o parâmetro número de

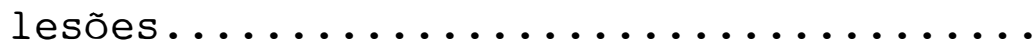

Figura 14- Quantificação de resistência horizontal e vertical incompleta em cultivares de feijoeiro para o parâmetro porcentagem de área foliar afetada.............. 


\section{LISTA DE TABELAS}

Página

Tabela 1 - Lista de identificação dos isolados de Alternaria spp., obtidos de folhas ou sementes de feijão, sua origem e número de

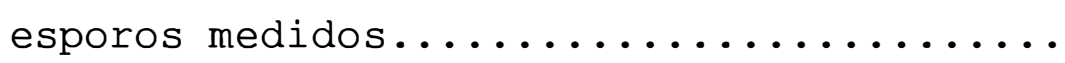

Tabela 2 - Valores utilizados para quantificação de RH e RVi nos cultivares mais suscetíveis de feijoeiro, quanto ao parâmetro número

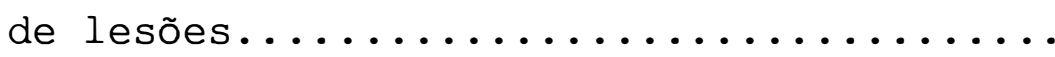

Tabela 3 - Valores utilizados para quantificação de RH e RVi nos cultivares mais resistentes de feijoeiro, quanto ao parâmetro número

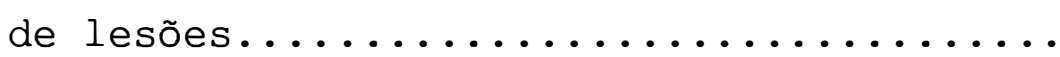

Tabela 4 - Valores utilizados para quantificação de RH e RVi nos cultivares mais suscetíveis de feijoeiro, quanto ao parâmetro porcentagem de área foliar afetada.......

Tabela 5 - Valores utilizados para quantificação de $\mathrm{RH}$ e RVi nos cultivares mais resistentes de feijoeiro, quanto ao parâmetro 
porcentagem de área foliar afetada........

Tabela 6 - Dimensões $(\mu \mathrm{m})$ dos esporos de isolados de Alternaria spp. do feijoeiro...........

Tabela 7 - Dimensões médias $(\mu \mathrm{m})$ dos esporos de isolados de Alternaria spp. do feijoeiro.. 45

Tabela 8 - Diâmetro médio das colônias de isolados de Alternaria spp. submetidas a diferentes

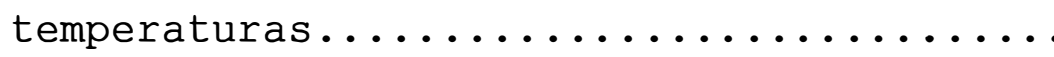

Tabela 9 - Equação da regressão polinomial para temperatura de crescimento máximo para os

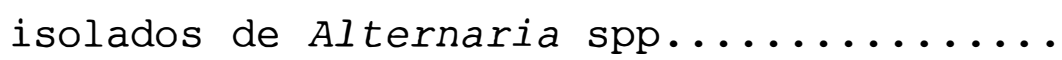

Tabela 10- Número de lesões causadas por isolados de Alternaria spp. em plantas de feijoeiro...

Tabela 11- Porcentagem de área foliar de feijoeiro afetada por isolados de Alternaria spp....

Tabela 12- Dados obtidos através dos testes de sanidade e emergência com sementes de feijoeiro, cultivar Carioca, inoculadas artificialmente com isolados de Alternaria spp........................

Tabela 13- Dados obtidos no teste de germinação de 
Página

sementes de feijão inoculadas
artificialmente com isolados de

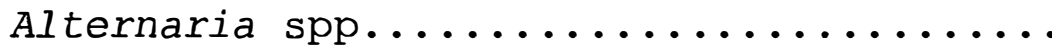




\title{
MANCHA DE ALTERNÁRIA DO FEIJOEIRO:
}

\section{ETIOLOGIA, RESISTÊNCIA DO HOSPEDEIRO E TRANSMISSÃO POR SEMENTES.}

\author{
Autora: Maria Heloisa Duarte de Moraes \\ Orientador: Prof. Dr. José Otávio M. Menten
}

RESUMO

Com o objetivo de verificar quais espécies de Alternaria estão causando a doença mancha de Alternária do feijoeiro, sua transmissão através das sementes e a resistência dos cultivares, desenvolveu-se este trabalho.

Através de características morfológicas e da análise eletroforética dos isolados, constatou-se a existência de, pelo menos, duas espécies causando a doença, sendo uma morfologicamente semelhante a Alternaria cichorii e outra a A. carthami. Quanto à patogenicidade, houve diferença entre as espécies e também entre seus isolados.

Para os 14 cultivares testados constatou-se a existência de resistência vertical incompleta a Alternaria 
carthami, havendo ampla variação no grau de resistência dos materiais testados e sendo os mais resistentes: Goiano Precoce, Jalo Precoce, Novo Jalo, IAC-Carioca e Cerro Azul. IAC-Carioca apresentou maior resistência horizontal a esta espécie e Goiano Precoce, Jalo Precoce e Novo Jalo apresentaram resistência vertical completa a um isolado.

Foi verificada a transmissão das espécies de Alternaria através das sementes e o efeito negativo de alguns isolados sobre a germinação. 


\section{ALTERNARIA LEAF SPOT OF COMMON}

\section{BEAN:ETIOLOGY, HOST RESISTANCE AND SEED}

\section{TRANSMISSION .}

Author: Maria Heloisa Duarte de Moraes Adviser: Prof. Dr. José Otávio M. Menten

SUMMARY

The objective of this paper was to verify which species of Alternaria cause Alternaria leaf spot of common bean, their transmission through seeds and cultivar resistance.

At least two species of Alternaria causing the disease were found on the basis of morphological characteristics and eletrophoretical analysis: one morfologically similar to $A$. cichorii and the other similar to $A$. carthami. With respect to pathogenicity, there was difference among species and among isolates within species of Alternaria. 
Incomplete vertical resistance to $A$. carthami was found among the cultivars tested, with a high degree of variation. The most resistant cultivars were: Goiano Precoce, Jalo Precoce, Novo Jalo, IAC-Carioca and Cerro Azul. IAC-Carioca showed the highest horizontal resistance to Alternaria carthami and Goiano Precoce, Jalo Precoce and Novo Jalo showed complete vertical resistance to only one isolate.

The seed transmission of the Alternaria species tested and the negative effect of some isolates on seed germination were detected. 


\section{INTRODUÇÃO}

A cultura do feijoeiro, no Brasil, deve sua importância ao fato de ser uma fonte importante de proteína na dieta da população, principalmente para a de baixa renda. Segundo Mariot (1989), em termos mundiais, o Brasil é o primejro em área cultivada e produção total de feijão. Porém, apesar da incorporação anual de novas áreas para produção, sua produtividade é baixa $(500 \mathrm{~kg} / \mathrm{ha})$, o que torna o rendimento físico médio das lavouras brasileiras um dos mais baixos do mundo. Este problema poderia ser superado visto que culturas adequadamente conduzidas possibilitam a expressão do potencial produtivo da espécie, que chega a 2500-3000 kg/ha (Fancelli, 1988).

Juntamente com outros fatores, as doenças causadas por fungos, bactérias e vírus têm sido uma das principais causas dessa baixa produtividade, sendo antracnose, mancha angular, ferrugem, crestamento bacteriano e mosaico comum consideradas as mais importantes. Nos últimos anos a mancha 
de Alternária, uma doença considerada de importância secundária para essa cultura, tem se mostrado bastante destrutiva, provavelmente pelas mudanças ocorridas no sistema de plantio que passou do convencional para intensivo sob pivô, em muitas áreas (Menezes, 1995).

Pelo fato de sua importância estar sendo reconhecida mais recentemente, pouco se conhece sobre essa doença. Não se sabe ao certo se uma ou mais espécies são causadoras dos sintomas e quais são essas espécies; a maioria dos autores denomina o agente causal de Alternaria sp.

As principais medidas de controle para essa doença seriam o uso de sementes livres do patógeno e uso de cultivares resistentes, sendo que também não existem muitos dados referentes a sua transmissão através das sementes e sobre a resistência dos cultivares.

Este trabalho teve, então, como objetivos caracterizar taxonômicamente diferentes isolados de Alternaria spp., avaliar a resistência de diversos cultivares de feijoeiro, detectar se há diferença entre os isolados quanto à patogenicidade e avaliar a transmissão desses isolados das sementes para as plantas de feijoeiro. 


\section{REVISÃO DE LITERATURA}

A doença denominada mancha de Alternária ou mancha parda era considerada de pouca importância, em lavouras de feijoeiro, devido à sua ocorrência esporádica e também ao fato de que, apesar de causar desfolha prematura, não causava grandes prejuizos (Shands et al., 1964; Diaz Polanco \& Casanova, 1966; Mohan et al., 1980 e Hall, 1991). Porém, sua incidência e severidade vêm aumentando consideravelmente nos últimos anos, principalmente nos estados do Espírito Santo, São Paulo, Zona da Mata em Minas Gerais e, mais ultimamente em áreas irrigadas de Goiás (Sartorato \& Rava, 1994).

Segundo Menezes ${ }^{1}$, a doença tem ocorrido sob altas temperaturas, em cultivo intensivo sob pivô, sendo que o dano é maior no segundo cultivo; a severidade varia de lavoura para lavoura e os cultivares de feijão preto têm se mostrado mais resistentes.

'MENEZES, J. R. (Samambaia Empreendimentos Agrícola). Goiânia / GO, 1996. 


\title{
2.1. Ocorrência da mancha de Alternária e danos causados em feijoeiro
}

\begin{abstract}
Neergaard ${ }^{2}$, citado por Swank (1951), relatou ocorrência de mancha de Alternária em feijoeiro, ocorrida no ano de 1894. No ano de 1951 a doença foi relatada na Flórida Central causando considerável dano a cerca de 50 ha de feijoeiro (Swank, 1951). Segundo Saad \& Hagedorn (1969), em 1964 e 1965 foi relatada pela primeira vez no estado de Wisconsin. Em Cambridge, houve ocorrência de Alternaria alternata causando uma severa mancha de folhas e vagens nos anos de 1974 e 1976 (Russel \& Brown, 1977 ).
\end{abstract}

No Brasil, segundo Vieira (1983), essa moléstia foi registrada em 1934, no estado de Minas Gerais, por Muller, e em São Paulo por Campacci, no ano de 1961. Atualmente sua ocorrência está generalizada, sendo constatada em outros estados. Levantamento realizado em Minas Gerais mostrou que em 1985, 10\% das lavouras observadas apresentaram ocorrência da doença e 8,2\% no ano de 1986 (Goulart, 1988).

\footnotetext{
${ }^{2}$ NEERGAARD, P. Danish species of Alternaria and Stemphylium. Humphrey Millford, Oxford Univ. Press., London. 1945 .
} 
No estado do Espírito Santo constatou-se a doença na safra das águas $(7,14 \%$ das lavouras) e na safra da seca $(10 \%$ e $30,7 \%$ ) nos anos de 1981 e 1982, respectivamente(Santos et al., 1984). Ensaios conduzidos na Estação Experimental do IAC, em Capão Bonito, mostraram que a mancha de Alternária vem ocorrendo todos os anos desde 1983, tanto na safra da seca quanto na das águas (Castro, 1988). Segundo Oliveira \& Castro (1991) a doença atingiu 30 a 50\% de infecção foliar, aos 82 dias após emergência, no campo experimental de Capão Bonito.

\subsection{Sintomatologia e etiologia da mancha de Alternária do feijoeiro}

Os sintomas típicos causados por Alternaria spp. na planta do feijoeiro iniciam, nas folhas, como lesões pequenas, irregulares, marrom avermelhadas com 0 bordo marrom escuro. Estas lesões aumentam de tamanho, tornam-se circulares com zonas concêntricas; sua porção mais velha pode cair, formando um orifício no centro. As manchas frequentemente coalescem formando grandes áreas de tecido morto e ocorrendo desfolha da planta. Os sintomas de manchas podem se apresentar em outras partes da planta, 
tais como vagens, caules, pecíolos e pedúnculos. Trabalho realizado com feijão vagem descreve o sintoma causado nas vagens por Alternaria alternata como: pontuações pequenas, irregulares e aquosas que evoluem, coalescendo e produzindo longas estrias ou áreas largas irregulares; zonas infectadas são de coloração avermelhada a marrom escura ou preta, deprimidas ou elevadas; normalmente, uma camada corticosa forma-se entre as lesões (Zawmeyer \& Thomas, 1957). Outro tipo de sintoma foi observado por Issa \& Ramos (1980) envolvendo mau desenvolvimento da planta, com sintomas de murcha evoluindo até necrose. Em Capão Bonito há relato de ocorrência de manchas foliares não concêntricas e queda de folhas causadas por uma espécie ainda não identificada de Alternaria (Ito et al., 1989).

Existem, na literatura, constatações de diversas espécies desse gênero como sendo agentes causais da doença mancha de Alternária em feijoeiro, mas não existe um consenso entre os autores sobre a etiologia da doença. Segundo Kimati (1980), Alternaria brassicae phaseoli é o patógeno responsável pela doença. Schwartz \& Galvez (1980) citam diversas espécies comó sendo causadoras da mancha da folha e da vagem: Alternaria tenuis, A. brassicae f. phaseoli e A. fasciculata. Segundo Neergaard, citado por Swank (1951), Alternaria brassicae f. phaseoli foi 
associada à doença em feijoeiro ocorrida em 1894, na Dinamarca. A. tenuis foi relatada como agente causal da mancha de folha ocorrida em Wisconsin, nos anos de 1964/65 (Saad \& Hagedorn, 1969); como agente causal do mosqueado da vagem no estado de Nova York, em 1974 e 1976 (Abawi et al., 1977) e também como causadora da queima do feijoeiro em Aguaí/ SP, no ano de 1978 (Issa \& Ramos, 1980).

\subsection{Diferenciação das espécies de Alternaria.}

o agente causal da mancha de Altenária pertence ao gênero Alternaria. Em meio de cultura, este fungo produz colônia expandida, normalmente cinza, marrom escura ou preta. O micélio é todo imerso ou parcialmente superficial; a hifa é de coloração marrom olivácea a marrom. o conidióforo pode permanecer simples, com um único poro no seu ápice produzindo um único conídio, ou pode tornar-se geniculado através do crescimento renovado de sua célula apical em uma região lateral ao poro; possuem coloração 'marrom pálida ou marrom. o esporo é catenulado ou solitário, tipicamente ovóide ou obclavado, frequentemente rostrado, marrom pálido ou oliváceo, ou marrom, liso ou 
verrugoso, com septos transversais e frequentemente também oblíquos ou longitudinais (Simmons,1967 e Ellis, 1971).

A identificação do fungo Alternaria, a nível de gênero não é difícil, pois seus esporos são típicos e fáceis de serem diferenciados de outros gêneros semelhantes. Apesar disso, antigamente muitas espécies hoje reconhecidas como de Alternaria eram denominadas Macrosporium (Elliot, 1917); de outro lado tem-se o exemplo do fungo Trichoconis padwikii que era denominado Alternaria padwikii (Ellis, 1971). Outros gêneros que podem ser confundidos com Alternaria são Stemphylium e Ulocladium, porém estes nunca formam cadeia e produzem esporos com extremidades arredondadas e sem bico (Simmons, 1967 e Ellis, 1971)

Através da literatura existente pode-se verificar que a dificuldade para se chegar a nível de espécie é uma constante. Segundo Ellis (1971), Elliot, Joly e Neergaard têm agrupado espécies de Alternaria de diferentes modos; esse autor reuniu 27 espécies desse gênero da seguinte maneira: as que formam longas cadeias e as que formam cadeias curtas ou não formam cadeias. Dentro deste último grupo, elas foram reagrupadas de acordo com a transição (abrupta ou suave) do corpo do esporo para o bico, e 
comprimento do bico (curto ou longo) em relação ao comprimento do corpo.

Apesar das diversas maneiras de se agrupar as espécies de Alternaria, as dificuldades e incertezas para se colocar um isolado em determinada espécie permanece; os problemas derivam, por um lado, da semelhança morfológica de várias espécies e de outro lado, das diferenças entre vários isolados de uma mesma espécie.

Neergaard ${ }^{3}$ citado por Rotem (1994), detalha as diferenças entre vários isolados da mesma espécie; as diferenças morfológicas de alguns desses isolados frequentemente são desvios das dimensões médias. Também segundo Rotem (1994), diversos autores relatam dados diferentes para a mesma espécie, talvez como resultado da variabilidade inerente ao gênero. Para este autor, a taxonomia de espécies de Alternaria é complicada pela variabilidade em seus caracteres morfológicos, que são afetados por condições ambiente e também por fatores intrínsecos. Em meio de cultura, o tamanho do esporo é geralmente menor que no hospedeiro natural; algumas

\footnotetext{
${ }^{3}$ NEERGAARD, P. Danish species of Alternaria and Stemphylium. Humphrey Millford, Oxford Univ. Press., London. 1945 .
} 
espécies que sobrevivem em restos culturais, mostram um desenvolvimento secundário que altera as características de forma e tamanho dos esporos (Elliot, 1917). Vakalounakis \& Christias (1985) demonstraram que comprimento e largura do corpo do esporo foram afetados por baixa e alta temperatura $\left(15^{\circ}\right.$ e $\left.33^{\circ} \mathrm{C}\right)$ e intensidade de $\operatorname{luz}(160$ e $1240 \mathrm{lx.})$, enquanto que o comprimento do bico foi afetado por baixa temperatura $\left(15^{\circ} \mathrm{C}\right)$ e pelas mesmas intensidades de luz já citadas; esporos obtidos de plantas infectadas mostraram dimensões diferentes.

Para identificação de uma espécie, alguns critérios morfológicos parecem ser mais importantes que outros; o caráter bico ajuda a distinguir espécies claramente diferentes, mas não as que são semelhantes. As dimensões do corpo do esporo, incluindo o bico, são consideradas as mais importantes características de uma espécie; dentre essas dimensões, o comprimento do esporo parece ser mais relevante que sua largura na parte mais larga (Rotem, 1994)

Contudo, a literatura mostra uma variação muito grande para as dimensões do corpo, pois estas podem ser modificadas por diversas causas, e em cada trabalho realizado as condições podem ser diferentes. Vakalounakis \& Christias (1985) demonstraram que a variabilidade das 
dimensões numa mesma espécie pode resultar de inúmeros fatores, sendo que o mais comum é a influência do substrato, temperatura e intensidade de luz.

Todas essas considerações demonstram a dificuldade que existe para classificar o fungo Alternaria a nível de espécie. Para superar este problema existe a possibilidade de se utilizar eletroforese de proteínas e isoenzimas. Segundo Alfenas (1991), esta técnica empregada na taxonomia de fungos é especialmente útil na distinção de espécies com pequenas diferenças morfológicas ou que não esporulam em meio de cultura.

Proteínas solúveis presentes no extrato cru de micélio fúngico, ou liberadas pelo fungo no meio de cultivo, podem ser separadas em géis de amido ou poliacrilamida, por meio de eletroforese, e o gel revelado para a visualização das proteínas totais ou zonas contendo atividade de enzimas específicas. A presença ou atividade é, normalmente, visualizada na forma de bandas coloridas com diferentes mobilidades. Para muitos gêneros estudados, as diferenças interespecíficas nos padrões protéicos obtidos são maiores que as diferenças intraespecíficas podendo-se portanto, utilizar com segurança estes padrões para distinguir espécies afins nestes gêneros (Alfenas \& Brommonschenkel, 1989). 
Rotem (1994) cita que Petrunak e Christ (1992) caracterizaram 54 isolados de Alternaria solani e 96 de A. alternata, de diferentes hospedeiros e diferentes locais, através de eletroforese de amido, detectando 35 tipos eletroforéticos.

Avaliando diversos isolados de $A$. solani das culturas de tomate e batata, Fancelli (1991) conseguiu estabelecer diferenças entres estes, através da análise eletroforética.

Outro critério que pode ser utilizado para diferenciação de espécies ou isolados de Alternaria é a temperatura ótima de crescimento em meio de cultura. Saad \& Hagedorn (1970), estudando três isolados patogênicos de $A$. tenuis, constataram que estes se desenvolveram bem sob ampla faixa de temperatura $\left(20^{\circ}-32^{\circ} \mathrm{C}\right)$, sendo que o ótimo de crescimento foi a $28^{\circ} \mathrm{C}$. Outros trabalhos citados por esses autores confirmam a temperatura de $28^{\circ} \mathrm{C}$ como a melhor para o desenvolvimento de Alternaria tenuis, $A$. tenuissima e $A$. multirostrata. Fancelli (1991) constatou que isolados de Alternaria solani, provenientes da cultura do tomate, tiveram um maior crescimento que aqueles provenientes da batata, em todas as temperaturas testadas. 


\subsection{Resistência dos cultivares de feijoeiro a Alternaria spp.}

Uma das medidas mais eficientes para o controle de doenças é o uso de cultivares resistentes. Para o caso da mancha de Alternária em feijoeiro, esta prática ainda não é muito utilizada pois, conforme Bulisani et al.(1987), "por se tratar de moléstia de expansão recente em nossas condições, inexistem variedades resistentes".

Provavelmente devido à pouca importância que se dava à doença, somente nos últimos anos é que os pesquisadores têm se preocupado em avaliar essa doença nos experimentos para melhoramento; portanto, existem poucos trabalhos referentes ao assunto. Castro et al. (1988) evidenciaram, sob condições de campo, boas fontes de resistência. Os cultivares que apresentaram menor incidência da doença foram: Roxinho Precoce, Jalo EEP 558, Cerro Azul, Pintado, Moruna 80, Bolinha e Lustroso.

Estudos feitos em Aguaí/SP, por Issa \$ Ramos (1980), mostraram que os cultivares Goiano Precoce, Pintado, Rosinha CIA 63, Roxinho Ribeirão, Jalo e Iguaçu não apresentaram sintomas de queima de Alternária. O cultivar Carioca mostrou-se moderadamente suscetível e Rosinha G-1, Rosinha G-2, Rico 23 e Abaeté 2 moderadamente resistente. 
Ito et al.(1989) observaram que os cultivares Carioca, Carioca-80, Cerro Azul e Rosinha foram suscetíveis a uma nova mancha de Alternária ocorrendo em Capão Bonito.

Em experimentos conduzidos nos anos de 1990 e 1991, Castro et al. (1991) constataram que os materiais Jalinho (Itararé), Pintado Rajado (CB), Pintado Pitoco (CB) e IPA-6 apresentaram resistência à doença. Estes mesmos autores avaliaram 87 cultivares de feijão, período da seca ao das águas de 1993, e observaram que 39 deles foram resistentes à doença mancha de Alternária (Castro et al., 1994). Oliveira et al. (1991) constataram que o cultivar Emgopa Ouro foi mais resistente à moléstia que Aeté-3, quando testados em diferentes locais do Estado de São Paulo.

\subsection{Transmissibilidade de Alternaria spp. através das sementes de feijão}

Um grande número de agentes causais de doenças de plantas pode ser transportado e transmitido através das sementes, sendo essa transmissão bastante eficiente, pois a doença está em íntima associação com a mesma. A importância dessa associação reside no fato que ao levar a semente infectada para o campo, pode-se estar introduzindo o 
patógeno em uma área isenta ou, então, estar aumentando a quantidade de inóculo já existente, contribuindo assim para o aumento da incidência da moléstia. Além disso, o patógeno presente na semente pode afetar a germinação ou o vigor da mesma, prejudicando o estabelecimento do estande( Menten, 1995) .

No caso de espécies de Alternaria sendo transportadas por sementes de feijoeiro, sabe-se que podem afetar a qualidade fisiológica das sementes, porém a principal preocupação é quanto a sua transmissão para áreas de cultivo, pois o problema causado pela doença mancha de Alternária vem se tornando cada vez mais grave, principalmente em cultivo intensivo sob pivô. Existem vários relatos de sementes de feijão transportando Alternaria spp., porém poucos pesquisadores estudaram o seu efeito sobre as sementes e a taxa de transmissão. Richardson (1979 e 1983) cita Alternaria brassicicola e $A$. alternata como sendo transportadas pelas sementes de feijão.

Em termos de Brasil, no Distrito Federal, constatouse a presença de Alternaria sp. na metade das amostras, sua incidência variando de 0,5 a $27,5 \%$ e sendo este último número bastante significativo quando se considera a introdução do patógeno em áreas isentas (Charchar et al., 
1988). Sementes de feijão produzidas nos anos de 1983 a 1986, no estado da Bahia, mostraram incidência de $A$. tenuis (Oliveira \& Mello, 1988); todas as amostras obtidas em nove municípios de Santa Catarina apresentaram incidência de $A$. tenuis e A. Ionguissima (Nunes Jr. \& Menten, 1985); no Paraná, 7,4\% dos lotes de feijão analisados eram portadores de Alternaria spp. (Menezes et al., 1981).

No estado de São Paulo um número bastante significativo de lotes de sementes apresentaram incidência de $A$. tenuis $(98,5 \%$ dos lotes) e de Alternaria spp. $(33,1 \%)$, sendo que a porcentagem das sementes foi maior para $A$. tenuis (Furlan \& Menten, 1989). Lasca (1978), analisando inúmeras amostras de sementes de feijão, sendo a maioria do estado de São Paulo, detectou a presença de Alternaria sp. em13,9\% das amostras analisadas pelo métsodo do papel de filtro e em $30,2 \%$ dsas amostras quando o método utilizado foi plaqueamento em BDA (batata-dextrose-ágar). Patrício et al. (1991) constataram uma incidência média de Alternaria spp. de 2,5\%, em sementes genéticas e básicas do estado de São Paulo, no ano de 1989 e de 4,5\% no ano de 1990 .

Estudos realizados por Rolim et al. demonstraram que sementes inoculadas com diferentes isolados de Alternaria sp. produziram plântulas com lesões na radícula e na parte aérea, constatando-se assim sua 
patogenicidade. Observaram também o efeito negativo dos isolados na emergência de plântulas. Gomes \& Dhingra (1983) relataram que sementes de feijão vagem, apresentando sintomas de infecção por $A$. tenuis, geralmente não germinam e que, as que não apresentam sintomas, mas são portadoras do fungo, germinam mostrando sintomas nos cotilédones e folhas primárias, sendo que estas lesões se tornam fontes de inóculo para outras plantas. 


\section{MATERIAL E MÉTODOS}

\subsection{Isolamento de espécies de Alternaria do feijoeiro}

Folhas de plantas de feijoeiro, apresentando sintomas da doença mancha de Alternária, foram coletadas de áreas produtoras ou de áreas experimentais de várias regiões, e trazidas para o Laboratório de Sanidade de Sementes do Depto. de Fitopatologia - ESALQ/USP, a fim de se isolar o patógeno. Para tanto, fez-se assepsia das folhas com hipoclorito de sódio a 1\%, durante 3 minutos e em seguida, estas foram colocadas em placas de Petri de plástico contendo duas folhas de papel de filtro umedecidas com água destilada. Estas foram deixadas sob condições ambiente, durante três dias. Após este período, foi observado o crescimento do fungo sobre a lesão e efetuada a transferência para meio de cultura (BDA) a fim de se - obter colônias puras dos isolados. 
Alguns isolados do patógeno foram obtidos de sementes, utilizando-se o método do papel de filtro segundo Lucca $F^{0}$ (1987) . Foram colocadas 10 sementes de feijão em cada placa de Petri de plástico contendo três folhas de papel de filtro umedecidas em água destilada e estas foram incubadas em câmara com temperatura de $20 \pm 2^{\circ} \mathrm{C}$ e fotoperíodo de $12 \mathrm{~h}$ de luz fria /12h de escuro, durante 7 dias. Após este período, as placas foram retiradas da câmara e esporos do fungo desenvolvidos sobre as sementes foram transferidos para placas de Petri contendo BDA, para obtenção de colônias puras.

A partir destes isolamentos, foram obtidas colônias monospóricas com as quais desenvolveram-se todos os trabalhos posteriores.

\subsection{Preservação dos isolados de Alternaria spp. do} feijoeiro

Inicialmente os isolados de Alternaria spp. obtidos foram preservados recobrindo-se a colônia do fungo, desenvolvida em tubos de ensaio contendo meio de cultura BDA, com óleo mineral (Nujol) esterilizado. Foi observado que, neste método, a maioria dos isolados patogênicos 
perdia a capacidade de esporular, após algum tempo de conservação. Desse modo, efetuou-se a preservação dos isolados em caule de feijoeiro esterilizado por autoclavagem, de onde foram recuperados com maior rapidez e sem perda de sua patogenicidade.

Esse método consistiu em se colocar pedaços de $5 \mathrm{~cm}$ de caule de feijoeiro em tubos de ensaio, contendo $3 \mathrm{ml}$ de água destilada. Os tubos assim preparados foram esterilizados em autoclave, a $120^{\circ} \mathrm{C}$, durante 20 minutos. Após esta esterilização efetuou-se a transferência de pequenos discos de colônias puras dos isolados de Alternaria spp. para os pedaços de caules; os tubos permaneceram em câmara de incubação sob temperatura de $20 \pm$ $2^{\circ} \mathrm{C}$ e luz alternada (12h de luz N.U.V./12h de escuro), durante 7 dias. Após este período, os tubos foram colocados em geladeira para conservação do material.

\subsection{Caracterização morfológica dos isolados de Alternaria spp. do feijoeiro}

Com o objetivo de comparar as diferenças morfológicas dos isolados de Alternaria spp., esporos foram produzidos em meio de tomate $(200 \mathrm{ml}$ de suco de tomate superbom 
integral, $800 \mathrm{ml}$ de água destilada, $15 \mathrm{~g}$ de ágar e 4,5 g de CaC03), pois segundo Dalla Pria \& Bergamin $F^{0}$ (1995) este meio estimula a esporulação deste patógeno. Os isolados de Alternaria spp. foram repicados para placas de Petri contendo o meio de cultura e mantidos sob temperatura de 20 $\pm 2^{\circ} \mathrm{C}$ e alternância de luz $(12 \mathrm{~h}$ de luz NUV/ $12 \mathrm{~h}$ de escurol, durante 15 dias. Após este período foram feitas lâminas semi-permanentes dos esporos produzidos. Foram determinados a largura e o comprimento do corpo do esporo, o comprimento do bico, o comprimento total (corpo + bico) e - número de septos transversais. Estas medições foram efetuadas sob microscópio composto (Bausch \& Lomb), na objetiva de 40x e ocular 10x (Fillar Micrometer Eyepiece Bausch \& Lomb), perfazendo um aumento de $400 x$.

Foi necessário medir um número diferente de esporos para cada isolado, devido à ocorrência de grande variação intra-específica. A fim de se determinar o número ideal de esporos a serem medidos, fez-se uma primeira medição de 30 para cada isolado (amostra piloto) e os dados obtidos foram aplicados na seguinte fórmula:

$$
\mathrm{n}=\left[\begin{array}{lll}
\left(t_{\alpha / 2}\right. & s) & / e_{0}
\end{array}\right]^{2} \text { (Rodrigues, 1976) }
$$


onde

$\mathrm{n}=$ tamanho da amostra;

$t_{\alpha / 2}=$ dado obtido de tabela $t$ de student (distribuição de probabilidade $t$ ao nível $\alpha$ de significância);

$$
\begin{aligned}
& \mathrm{S}=\text { desvio padrão (obtido da amostra piloto); } \\
& \mathrm{e}_{0}=/ \mu-\mathrm{x} / \text {, onde } \mu \text { significa o valor médio da }
\end{aligned}
$$
amostra e X significa a média da amostra piloto. O valor de e admitido foi 10,0 .

Na Tabela 1 encontram-se listados os isolados de Alternaria spp., sua origem e o número de esporos que foram medidos. Todos os isolados foram obtidos de folhas ou sementes oriundas do estado de São Paulo; os isolados 2 e 6 pertencem à espécie tipo Alternaria alternata, que produzem esporos pequenos em cadeias longas, enquanto que os demais foram denominados, a princípio, de Alternaria sp. produzindo os esporos isoladamente e sendo objeto de estudo deste trabalho de caracterização. 
TABELA 1: Lista de identificação dos isolados de Alternaria spp., obtidos de folhas ou sementes de feijão, sua origem e número de esporos medidos.

\begin{tabular}{lcccc}
\hline Isolados & Cultivar & Órgão & Origem & Número de \\
& & & & Esporos \\
\hline 1 Alternaria sp. & Carioca & Folha & Capão Bonito/SP & 100 \\
2 A. alternata & Carioca & Folha & Guaíra/SP & 60 \\
3 Alternaria sp. & Carioca & Semente & $*$ & 70 \\
4 Alternaria sp. & Carioca-80 & Folha & Pardinho/SP & 30 \\
5 Alternaria sp. & Carioca & Folha & Guaíra/SP & 100 \\
6 A. alternata & Carioca & Folha & Guaíra/SP & 30 \\
7 Alternaria sp. & Carioca & Folha & Cosmópolis/SP & 70 \\
8 Alternaria sp. & Carioca & Folha & $*$ & 60 \\
9 Alternaria sp. & Carioca & Semente & $*$ & 70 \\
10 Alternaria sp. & $*$ & Folha & $*$ & 80 \\
11 Alternaria sp. & Carioca & Semente & $*$ & 45 \\
\hline * Dados inexistentes & & & & \\
\hline
\end{tabular}


3.4. Caracterização cultural dos isolados de Alternaria spp.

A caracterização cultural dos isolados foi feita em dois meios de cultura, BDA e tomate, observando-se o tipo de colônia produzida quanto à formação de micélio, esporulação e coloração do meio.

3.5. Caracterização eletroforética dos isolados de Alternaria spp.

Este experimento, com exceção do desenvolvimento dos isolados, foi conduzido no laboratório do Instituto Biológico, em São Paulo / SP.

\subsubsection{Desenvolvimento dos isolados em meio líquido}

Para efetuar a extração de proteínas e analisar o perfil eletroforético dos isolados de Alternaria spp. foi realizado o cultivo destes fungos em meio líquido de batata-dextrose, segundo Bach (1991). O meio foi distribuído em erlenmeyers com capacidade de $250 \mathrm{ml}$, colocando-se $100 \mathrm{ml}$ para cada frasco. Discos de micélio de 5 mm de diâmetro, provenientes da periferia de colônias de 
Alternaria spp. produzidas em BDA, foram transferidos para os erlenmeyers que foram incubados a uma temperatura de 20 $\pm 2^{\circ} \mathrm{C}$, durante 10 dias.

Após esse período, a massa micelial contida em cada frasco foi retirada separadamente e lavada com água destilada estéril, por filtração em funil Buchner e papel de filtro (Whatmann $\mathrm{n}^{0} 1$ ). A seguir, a massa micelial foi secada à temperatura ambiente e pesada, obtendo-se o seu peso de matéria fresca. Para obtenção do peso de matéria seca, vidros de penicilina foram colocados em estufa a $80^{\circ} \mathrm{C}$ por 24 horas e tarados; a seguir foram colocados nestes mesmos frascos uma certa quantidade de micélio fresco, que também foi mantida a $80^{\circ} \mathrm{C}$, até obtenção de peso constante.

Com o intuito de se ter padrões para comparação, obtiveram-se isolados de espécies de Alternaria, seguramente denominadas. Não foi possível conseguir isolados de todas as espécies citadas para o feijoeiro, na literatura, ou das que se assemelham aos isolados deste estudo. As espécies obtidas foram: Alternaria brassicae, $A$. cucumerina (cedidas pelo Instituto Biológico / SP), $A$. dauci (isolada de sementes de cenoura) e A. porri (isolada de semente de cebola). 


\subsubsection{Extração de proteína dos isolados}

Triturou-se em almofariz $500 \mu \mathrm{g}$ de micélio seco de cada isolado, em banho de gelo, com $1 \mathrm{ml}$ de tampão Trisglicina $0,125 \mathrm{M}, \mathrm{pH}=8,2+10 \%$ sacarose $+300 \mathrm{mg}$ de polivinilpirrolidona (PVP). Após a trituração, as amostras foram mantidas a $4^{\circ} \mathrm{C}$ por um período de 4 horas, sendo depois filtradas em gaze. A parte filtrada constituiu-se de extrato proteico (Bach, 1991).

As amostras passaram por um processo de liofilização a fim de que se tornassem mais concentradas até $500 \mu \mathrm{g}$ de proteína / $\mathrm{ml}$.

\subsubsection{Determinação da concentração de proteínas nas amostras}

Através do método de Lowry (Bach, 1991; Bach \& Kimati, 1993), foi estimada a concentração de proteínas nos extratos

Para realizar estas quantificações foi necessário preparar previamente quatro reagentes. O reagente B1 consistiu de $1 \%$ de sulfato de cobre pentahidratado em água destilada, O B2 foi formado colocando-se tartarato de sódio a $2 \%$ em água destilada, 0 A consistiu de $2 \%$ de carbonato de 
sódio em hidróxido de sódio 0,1 N. A solução reagente C foi preparada misturando-se $0,5 \mathrm{ml}$ de cada reagente $\mathrm{B}$ e $49 \mathrm{ml}$ do reagente $A$.

Assim, o método consistiu em adicionar a cada 0,2 ml das amostras, $1 \mathrm{ml}$ da solução reagente $\mathrm{C}$, agitá-las e após 10 minutos adicionar $0,1 \mathrm{ml}$ do reagente Folin Ciocalteau 2 N (Qeel-Ind. Quim. São Paulo, SP), previamente diluído em água destilada $(1: 1, \mathrm{v} / \mathrm{v})$. As amostras foram agitadas e, após 30 minutos, foi realizada a determinação das respectivas absorbâncias no comprimento de onda de 500 nm, em cada amostra, expressa em termos de equivalentes $\mu \mathrm{g} / \mathrm{ml}$, em função de suas respectivas absorbâncias a $500 \mathrm{~nm}$.

\subsubsection{Preparo do gel de poliacrilamida}

Para a análise eletroforética dos isolados testados, foi utilizado o gel de poliacrilamida, que consiste numa reação de polimerização entre a acrilamida (AA) e metilenobis-acrilamida (BIS) na concentração de 5\%.

Após a dissolução de AA e do BIS em tampão Trisglicina $0,125 \mathrm{M}, \mathrm{pH}=8,2$, foi adicionado $0,1 \mathrm{ml}$ de tetrametildiamina (TEMED) e $2,8 \mathrm{ml}$ de persulfato de amônio na concentração de $2 \%$ Tal mistura foi colocada imediatamente, com auxílio de uma seringa de $25 \mathrm{ml}$, entre 2 
placas (19 x 19,5 cm), sendo uma de vidro e outra de polietileno, separadas entre si por intermédio de um espaçador de polietileno de $2 \mathrm{~mm}$ de espessura, contendo incluso um pente para 12 amostras. Após a polimerização completa do gel, o espaçador foi retirado e a placa de polietileno removida, ficando o gel na placa de vidro, que foi colocado em uma cuba de sistema horizontal, contendo tampão Tris-glicina 0,125 M, pH=8,2, fazendo-se uma conexão do gel com a solução, através de papel de filtro Whatmann $\mathrm{n}^{0} 3$ (Bach, 1991).

\subsubsection{Aplicação das amostras e corrida eletroforética}

Em cada cavidade do gel, formada pelo pente, foi aplicado $28 \mu l$ do extrato contendo $50 \mu g$ em equivalente de SAB. Imediatamente, foi realizada a corrida em aparelho horizontal marca Permatron, mantendo-se a corrente em $5 \mathrm{~mA}$ até o corante marcador sair da cavidade, passando depois para $10 \mathrm{~mA}$ até o final da corrida. O corante marcador utilizado foi o azul de bromofenol a 0,25\% em Tris-glicina, $\mathrm{pH}=8,2$, mais a sacarose a 10\%. As corridas eletroforéticas foram realizadas à temperatura de $10^{\circ} \mathrm{C}$. Para cada amostra foi repetida a corrida por três vezes (Bach, 1991). 


\subsubsection{Coloração}

Após a corrida eletroforética, os géis foram retirados das placas e imersos imediatamente na solução corante da esterase, que consistiu na dissolução de $50 \mathrm{mg}$ de "Fast red TR" em $100 \mathrm{ml}$ de tampão fosfato 0,1 M, pH=6,5, e a adição de $2 \mathrm{ml}$ de solução $1 \%$ de $\boldsymbol{\alpha}$-naftil acetato em 50\% de acetona. O gel foi deixado nesta solução por uma hora e depois fixado com ácido acético a 7\% (Jvo \& Stotaky, 1973), modificado por Bach (1989).

\subsubsection{Preservação dos géis}

Em seguida à coloração, os géis foram imersos em solução de metanol, ácido acético e água, na proporção de 50:75:100, contendo 10\% de glicerina (v/v), durante uma hora. Duas folhas de papel celofane também foram colocadas nesta solução por alguns minutos.

Uma placa de vidro foi envolta por uma das folhas de papel celofane, dobrando-se as bordas laterais deste por baixo da placa, tendo-se o cuidado de não deixar bolhas de ar entre a placa e o papel. Em seguida, colocou-se o gel sobre o celofane na placa, e, com a outra folha, cobriu-se o gel retirando-se todas as bolhas de ar existentes, 
envolvendo-o na placa de acordo com o procedimento anterior, deixando-se secar à temperatura ambiente. Depois da secagem, retirou-se o gel da placa de vidro, recortandose o excesso de papel celofane (Bach, 1991).

\subsubsection{Análise do perfil eletroforético}

Os perfis foram analisados com base no número, posição e intensidade das bandas (BACH, 1991); a cópia do gel foi feita por densitômetro Bio-Rad acoplado a computador 486-DX2, com programa Molecular Analyst.

\subsection{Desenvolvimento de colônias de isolados de}

\section{Alternaria spp. sob diferentes temperaturas}

Com o intuito de verificar se havia diferença entre os isolados quanto à taxa de crescimento da colônia sob determinadas temperaturas, procedeu-se à instalação do teste colocando-se um disco de $5 \mathrm{~mm}$ de diâmetro no centro de placas contendo meio de tomate (ítem 3.3.); estas placas foram levadas para germinador da Nipon - Medical Chemical Instruments, onde cada prateleira correspondia a uma temperatura, sendo estas de $10^{\circ}, 15^{\circ}, 20^{\circ}, 25^{\circ}$ e $30^{\circ} \mathrm{C}$. 
As avaliações foram realizadas no sexto dia de incubação, medindo-se o crescimento diametral médio das colônias, em dois sentidos perpendiculares entre si.

o delineamento experimental utilizado foi de blocos ao acaso, esquema fatorial 5 (temperaturas) x 11 (isolados), com 4 repetições.

3.7. Reação de cultivares de feijoeiro a diferentes isolados de Alternaria spp.

\subsubsection{Inoculação}

Este experimento foi conduzido no Departamento de Fitopatologia - ESALQ/USP, sob condições controladas, durante os meses de junho a dezembro de 1995.

Cultivares de feijoeiro, relatados como apresentando diferentes níveis de resistência a Alternaria spp., foram inoculados com os isolados do patógeno, sendo que os cultivares testados foram os seguintes: Carioca, IACCarioca, Aporé, IAPAR-14, MD-821 e IAPAR-57, pertencentes ao grupo diversos; Rio Tibagi e IAPAR-44, do grupo preto; Jalo Precoce, Novo Jalo e Goiano Precoce, do grupo 
manteiga; Rosinha, do grupo rosinha; Roxo-90, do grupo roxinho e Cerro Azul, do grupo chumbinho.

Para a produção do inóculo, os isolados de Alternaria spp. foram desenvolvidos em meio de tomate (ítem 3.3.), por estimular a esporulação. A incubação foi feita sob condições de $20 \pm 2^{\circ} \mathrm{C}$ de temperatura e luz alternada (12h. de luz NUV/12h de escuro), durante 15 dias. Preparou-se a suspensão de esporos colocando-se $5 \mathrm{ml}$ de água destilada e esterilizada sobre a colônia do fungo e efetuando-se raspagem com pincel a fim de soltar os esporos. Essa suspensão foi filtrada em gaze para separar pedaços de micélio. Após esse processo, adicionou-se Tween 80, para que os esporos não ficassem agregados e fez-se a calibração do inóculo, obtendo-se uma concentração de $10^{5}$ esporos por $\mathrm{ml}$.

A inoculação foi feita em plantas com 21 dias de idade, produzidas em casa-de-vegetação, pulverizando-se o inóculo na primeira folha trifoliolada com a suspensão de esporos, até a formação de um filme de água. As plantas inoculadas foram deixadas em sala sob condições de alta umidade relativa, temperatura de $22^{\circ}$ a $26^{\circ} \mathrm{C}$ e $12 \mathrm{~h}$ de luz branca + grow lux / $12 \mathrm{~h}$ de escuro, durante 10 dias. Após esse período foi efetuada a avaliação do experimento, através da contagem do número de lesões e a determinação da 
porcentagem de área foliar afetada, na primeira folha trifoliolada.

A avaliação dos isolados 8 e 11 foi feita 7 dias após a inoculação, pois o desenvolvimento da doença foi mais rápido, causando amarelecimento e queda prematura das folhas.

o delineamento experimental utilizado foi o inteiramente casualizado, constando de 4 repetições por tratamento; cada repetição consistiu de um vaso contendo duas plantas.

\subsubsection{Avaliação dos resultados}

A porcentagem da área foliar afetada foi avaliada comparando-se a folha trifoliolada inoculada com uma escala diagramática elaborada por Godoy et al. (1997), que pode ser observado na Figura 1. O número de lesões foi obtido fazendo-se a contagem em toda área da folha trifoliolada inoculada e a seguir, fazendo-se a conversão desse número para uma área de $25 \mathrm{~cm}^{2}$, pois o tamanho das folhas varia muito entre os cultivares. 


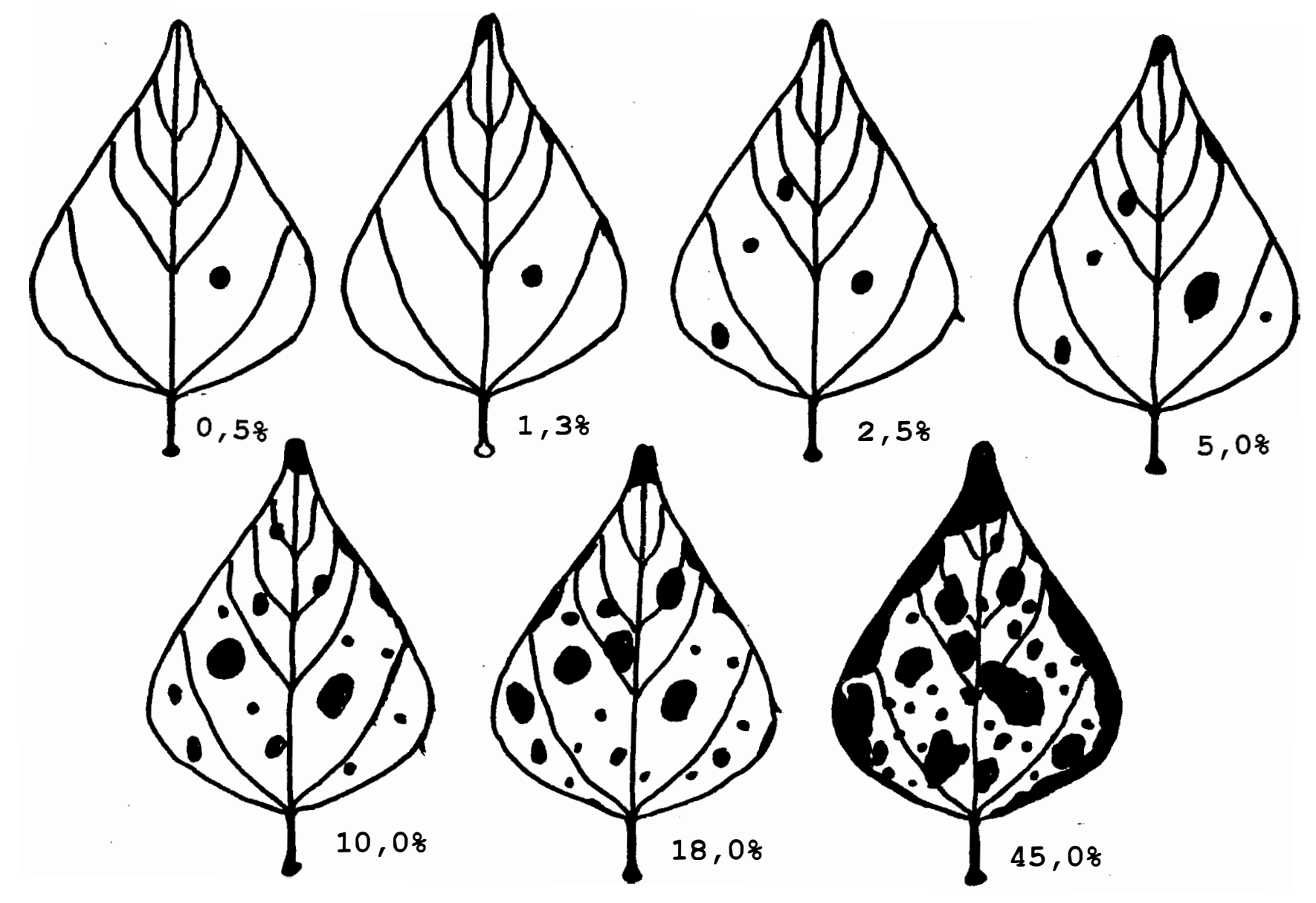

FIGURA 1: Escala diagramática de severidade (porcentagem de área foliar afetada) da mancha de Alternária do feijoeiro (Godoy et al., 1997). 
A área da folha trifoliolada foi estimada pela seguinte equação, obtida por Iamauti (1995):

$$
Y=2,137\left(x^{1,96}\right)-2,701
$$

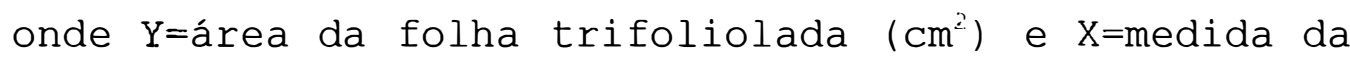
largura do maior folíolo da folha trifoliolada (cm).

\subsubsection{Quantificação da resistência}

Obtidos os resultados e efetuada a análise estatística, verificou-se interação diferencial significativa entre hospedeiro e patógeno, não havendo um ordenamento constante de variedades, segundo o grau de resistência, independentemente dos isolados do patógeno. Isso indica a existência de Resistência Vertical incompleta (RVi) na maioria dos cultivares testados (Vanderplank, 1968 e 1978) .

Para determinar $\circ$ quanto da resistência desses cultivares a Alternaria spp. é vertical incompleta (RVi) e quanto é horizontal (RH), foi feita análise similar àquela recomendada por Vanderplank (1978) e feita por Castro 
(1985), para o sistema Eucalyptus grandis X Puccinia psidii.

Para essa quantificação foram considerados os isolados 4, 5, 7, 8, 9, 10 e 11, pertencentes à espécie Alternaria carthami, segundo resultados obtidos neste trabalho, e os cultivares que se mostraram suscetíveis a eles. Os isolados 1 e 3, e 2 e 6 não foram incluídos por pertencerem à espécie A. cichorii e A. alternata, respectivamente, e apenas o 1 e 2 terem causado doença na maioria dos cultivares, enquanto que todos se mostraram completamente resistentes aos isolados 3 e 6 . No caso do isolado 3 apareceram algumas lesões pequenas, atípicas, que não esporularam indicando presença de R.V. completa em todos os materiais a este isolado, mascarando a R.V.i.

Para a quantificação, foi considerado o isolado que causou maior quantidade de doença nos cultivares testados, dentro de cada parâmetro avaliado (área foliar afetada e número de lesões por área foliar). Dentro de cada cultivar, separou-se o isolado mais virulento e fez-se a média dos demais; $O$ valor $\mathrm{T}$ foi obtido dividindo-se essa maior quantidade de doença pela quantidade causada pelo isolado mais adaptado a este cultivar ( $\mathrm{RH}$ ) e também pela média dos outros isolados (Rvi). Apenas para exemplificação, as Tabelas 2 e 4 apresentam os números que foram utilizados 
para quantificação da resistência para os cultivares IAPAR 44, Roxo-90, Aporé, IAPAR 57, Carioca, Rosinha, IAPAR 14, IAPAR 16 , Rio Tibagi, IAC-Carioca e Cerro Azul, para o parâmetro número de lesões e porcentagem de área foliar afetada, respectivamente.

Para os cultivares Novo Jalo, Jalo Precoce e Goiano Precoce (Tabelas 3 e 5) o procedimento foi o mesmo, porém excluiu-se o isolado 10 para o qual estes cultivares se mostraram completamente resistentes.

TABELA 2: Valores utilizados para quantificação de RH e RVi nos cultivares mais suscetíveis de feijoeiro, quanto ao parâmetro número de lesões.

\begin{tabular}{lcccc}
\hline Cultivar & $\begin{array}{c}\text { Isolado } \\
\text { mais } \\
\text { adaptado }\end{array}$ & $\begin{array}{c}\text { T } \\
(\mathrm{RH})\end{array}$ & $\begin{array}{c}\text { Média dos } \\
\text { demais } \\
\text { isolados }\end{array}$ & $\begin{array}{c}\text { T } \\
\text { (RVi) }\end{array}$ \\
\hline IAPAR 44 & 35,9 & 1,07 & 15,18 & 2,56 \\
Roxo-90 & 38,8 & 1,00 & 14,30 & 2,71 \\
Aporé & 36,0 & 1,08 & 14,12 & 2,75 \\
IAPAR 57 & 28,7 & 1,35 & 11,60 & 3,34 \\
Carioca & 24,6 & 1,58 & 11,90 & 3,26 \\
Rosinha & 24,5 & 1,58 & 11,30 & 3,43 \\
IAPAR 14 & 29,6 & 1,31 & 9.80 & 3,96 \\
IAPAR 16 & 29,6 & 1,31 & 9,93 & 3,91 \\
Rio Tibagi & 30,3 & 1,28 & 7,38 & 5,26 \\
IAC-Carioca & 16,4 & 2,36 & 7,67 & 5,05 \\
Cerro Azul & 23,7 & 1,64 & 3,83 & 10,13 \\
\hline
\end{tabular}

OBS: Maior quantidade de doença causada pelo isolado $8=38,8$ valor este que foi dividido pelas demais quantidades de doença, obtendo-se o valor $\mathrm{T}$. 
TABELA 3: Valores utilizados para quantificação de RH e RVi nos cultivares mais resistentes de feijoeiro, quanto ao parâmetro número de lesões.

\begin{tabular}{lcccc}
\hline Cultivar & $\begin{array}{c}\text { Isolado } \\
\text { mais } \\
\text { adaptado }\end{array}$ & $\begin{array}{c}\text { T } \\
\text { (RH) }\end{array}$ & $\begin{array}{c}\text { Média dos } \\
\text { demais } \\
\text { isolados }\end{array}$ & $\begin{array}{c}\text { T } \\
\text { (RVi) }\end{array}$ \\
\hline Novo Jalo & 31,4 & 1,00 & 7,84 & 4,24 \\
Jalo Precoce & 20,7 & 1,52 & 7,40 & 4,00 \\
Goiano Precoce & 17,9 & 1,75 & 7,84 & 6,65 \\
\hline OBS: Maior quantidade de doença causada pelo isolado \\
11=31,4, valor este que foi dividido pelas demais \\
quantidades de doença, obtendo-se o valor T.
\end{tabular}

TABELA 4: Valores utilizados para quantificação de $\mathrm{RH}$ e RVi nos cultivares mais suscetíveis de feijoeiro, quanto ao parâmetro porcentagem de área foliar afetada.

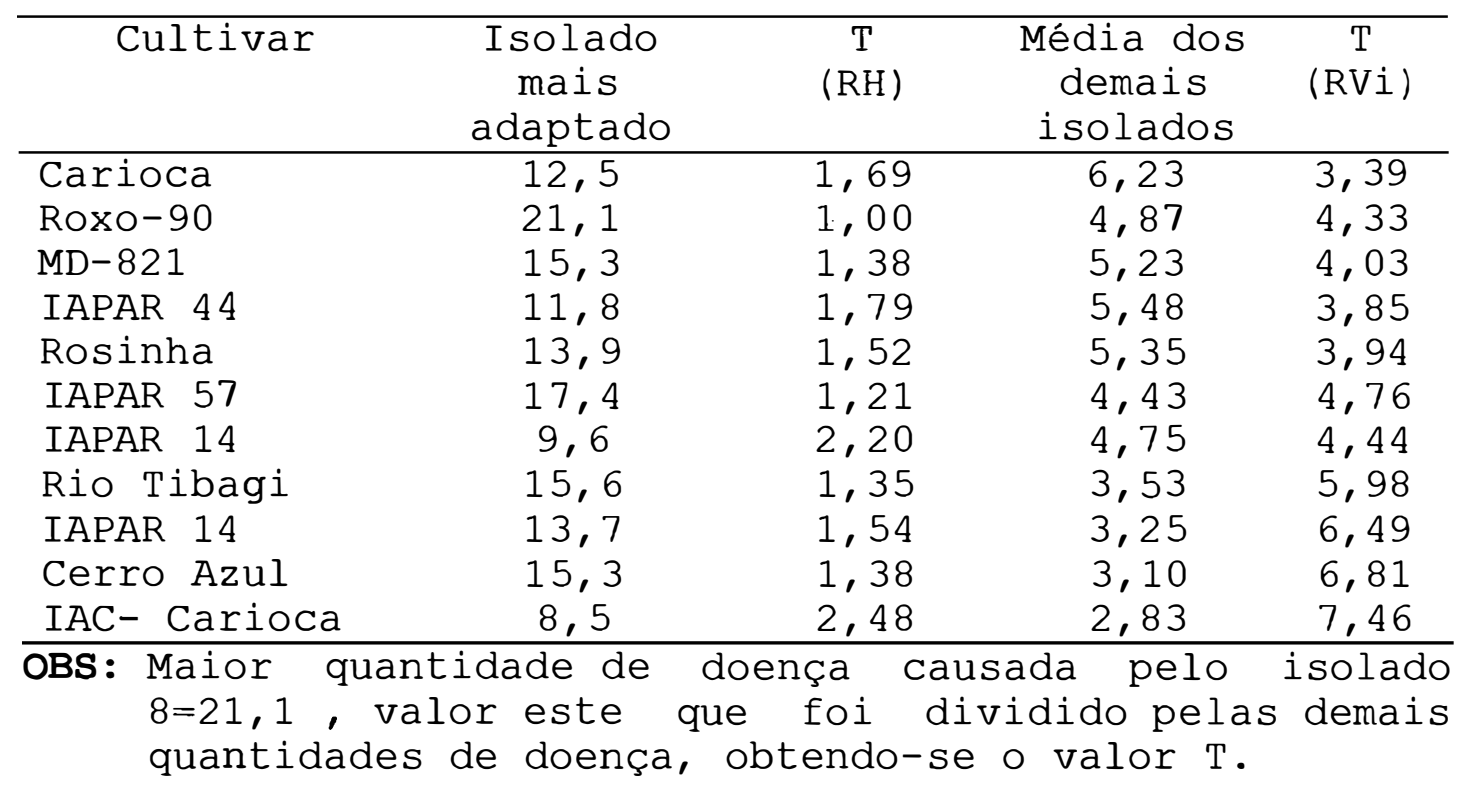


TABELA 5: Valores utilizados para quantificação de $\mathrm{RH} e$ RVi nos cultivares mais resistentes de feijoeiro, quanto ao parâmetro porcentagem de área foliar afetada.

\begin{tabular}{lcccc}
\hline Cultivar & $\begin{array}{c}\text { Isolado } \\
\text { mais } \\
\text { adaptado }\end{array}$ & $\begin{array}{c}\text { T } \\
\text { (RH) }\end{array}$ & $\begin{array}{c}\text { Média dos } \\
\text { demais } \\
\text { isolados }\end{array}$ & $\begin{array}{c}\text { T } \\
\text { (RVi) }\end{array}$ \\
\hline Novo Jalo & 12,8 & 1,12 & 2,80 & 3,09 \\
Jalo Precoce & 14,4 & 1,00 & 3,00 & 4,77 \\
Goiano Precoce & 10,9 & 1,32 & 1,48 & 9,73 \\
\hline OBS: Maior quantidade de doença causada pelo isolado \\
8=14,4 valor este que foi dividido pelas demais \\
quantidades de doença, obtendo-se o valor T.
\end{tabular}

3.8. Transmissão de Alternaria spp. através das sementes de feijão

3.8.1. Inoculação artificial das sementes com os isolados de Alternaria spp.

A fim de se obter amostras de sementes infectadas com os isolados do fungo para verificar seu transporte, transmissão e danos que podem causar à germinação e vigor das sementes, houve necessidade de se inocular artificialmente as mesmas. A inoculação foi feita através do método do contato (Rolim et al., 1990), utilizando-se o 
cultivar Carioca, um dos considerados mais suscetíveis a esse patógeno.

Para tanto, colônias dos 11 isolados foram produzidas em meio de tomate (ítem 3.3.), em câmara de incubação, sob condições de temperatura de $20 \pm 2^{\circ} \mathrm{C}$ e luz alternada (12h de luz NUV/12h de escuro). Quando as colônias ocuparam todo - espaço da placa, as sementes previamente submetidas à assepsia, foram colocadas nas placas (60/placa) de maneira a ficarem em contato com a colônia do patógeno, e deixadas na câmara de incubação por 48 horas. Passado este tempo, as sementes foram postas para secar sob condições ambiente até quase atingirem sua umidade inicial.

Para obtenção da amostra testemunha procedeu-se do mesmo modo, sendo que as sementes foram colocadas em contato direto com o meio de tomate.

\subsubsection{Testes em laboratório}

Após a inoculação das sementes com os diferentes isolados de Alternaria spp., estas foram submetidas ao teste de sanidade, através do método do papel de filtro, já descrito no ítem 3.1., a fim de se avaliar a eficiência da inoculação e quanto do patógeno a amostra de sementes estava transportando. Durante a avaliação só foram anotadas 
as sementes que apresentavam esporulação do fungo, não sendo consideradas as que apresentavam apenas desenvolvimento micelial.

Com o intuito de se verificar o efeito das espécies de Alternaria sobre sementes e plântulas, procedeu-se ao teste de germinação pelo método do rolo de papel, segundo as R.A.S. (Brasil, 1992). Os rolos, contendo 50 sementes cada, foram colocados em germinador De Leo tipo Mangelsdorf, à temperatura constante de $25^{\circ}$ C. As avaliações foram feitas aos 5 e 9 dias após instalação do experimento, sendo avaliados os seguintes parâmetros: plântulas normais, normais infeccionadas, anormais deformadas, anormais infeccionadas e sementes mortas. Foram consideradas como infecções as lesões características provocadas pelo fungo, no cotilédone.

o delineamento experimental para estes testes foi inteiramente casualizado, com 4 repetições, sendo analisadas 400 sementes por tratamento.

\subsubsection{Teste de emergência em casa-de-vegetação}

o teste de emergência em casa-de-vegetação foi efetuado para verificar a transmissão do patógeno das sementes para as plântulas e seu efeito sobre a emergência. 
Consistiu em semear as sementes inoculadas em caixa plástica de 30 x 40 X $10 \mathrm{~cm}$, contendo solo esterilizado. Foram colocadas 50 sementes por repetição, sendo duas repetições por caixa. As condições da casa-de-vegetação foram de alta umidade relativa, garantida por aspersão, e temperatura variando de $25^{\circ}$ a $35^{\circ} \mathrm{C}$.

A avaliação foi feita 15 dias após instalação do experimento anotando-se o número de plântulas que emergiram e de plântulas que apresentaram lesões características.

O delineamento experimental utilizado foi o de blocos casualizados, com 4 repetições por tratamento. 


\section{RESULTADOS E DISCUSSÃO}

\subsection{Caracterização de isolados de Alternaria spp. do feijoeiro}

\subsubsection{Caracterização morfológica}

As dimensões dos esporos de Alternaria spp., obtidos através de medições em microscópio composto, estão listadas nas Tabelas 6 e 7. A Tabela 6 apresenta os valores mínimo, máximo e a média e a Tabela 7 apresenta as diferenças estatísticas para as médias das medidas, obtidas através do teste de Tukey.

Através desses dados os isolados de Alternaria spp. foram agrupados para cada característica mensurada. o primeiro grupo, possuindo maior largura do corpo do esporo, é composto dos isolados 5, 7, 9 e 10. Os isolados 4 e 8, e 11, 1 e 3, formam os dois grupos intermediários e por 
TABELA 6: Dimensões $(\mu \mathrm{m})$ dos esporos de isolados de Alternaria spp.do feijoeiro

\begin{tabular}{llll|rrr|rrr|rrr}
\hline & \multicolumn{3}{c}{ Larg. do Corpo } & \multicolumn{3}{c}{ Comp. do Corpo } & \multicolumn{3}{c}{ Comp. do Bico } & \multicolumn{3}{c}{ Comp. Total } \\
Iso. & Mín & Máx & Méd & Mín & Máx & Méd & Min & Máx & Méd & Mín & Máx & Méd \\
\hline 1 & 14 & 22 & 18 & 53 & 113 & 84 & 21 & 390 & 90 & 92 & 454 & 174 \\
3 & 14 & 22 & 18 & 51 & 96 & 81 & 5 & 187 & 41 & 51 & 218 & 121 \\
4 & 16 & 27 & 21 & 64 & 100 & 84 & 6 & 59 & 11 & 75 & 130 & 96 \\
5 & 14 & 32 & 23 & 56 & 109 & 84 & 5 & 107 & 22 & 62 & 195 & 105 \\
7 & 17 & 28 & 23 & 56 & 107 & 83 & 6 & 192 & 42 & 76 & 249 & 125 \\
8 & 15 & 28 & 20 & 51 & 104 & 78 & 3 & 99 & 28 & 68 & 188 & 105 \\
9 & 17 & 30 & 24 & 64 & 120 & 96 & 6 & 80 & 17 & 62 & 184 & 113 \\
10 & 18 & 30 & 23 & 29 & 100 & 77 & 5 & 286 & 89 & 59 & 385 & 166 \\
11 & 14 & 25 & 19 & 54 & 100 & 72 & 4 & 32 & 10 & 62 & 113 & 82 \\
2 & 10 & 17 & 14 & 23 & 69 & 42 & 0 & 13 & 5 & 22 & 69 & 42 \\
6 & 12 & 17 & 14 & 31 & 57 & 46 & 0 & 15 & 6 & 31 & 57 & 46 \\
\hline
\end{tabular}


último os de corpo mais estreito, 2 e 6, pertencentes à espécie Alternaria alternata.

Para a característica comprimento do corpo do esporo, os isolados ficaram agrupados da seguinte maneira: 9, de esporo mais longo; 1, 3, 4, 5, 7 e 8 grupo intermediário, seguido dos isolados 10 e 11, e o grupo de esporo menor, 2 e 6 .

TABELA 7: Dimensões médias $(\mu \mathrm{m})$ dos esporos de isolados de Alternaria spp. do feijoeiro.

\begin{tabular}{lcccc}
\hline Isolados & $\begin{array}{c}\text { Largura do } \\
\text { corpo }\end{array}$ & $\begin{array}{c}\text { Comprim. do } \\
\text { corpo }\end{array}$ & $\begin{array}{c}\text { Comprim. do } \\
\text { bico }\end{array}$ & $\begin{array}{c}\text { Comprim. } \\
\text { total }\end{array}$ \\
\hline 1 & $18 \mathrm{~d}^{*}$ & $84 \mathrm{~b}$ & $90 \mathrm{a}$ & $174 \mathrm{a}$ \\
3 & $18 \mathrm{~d}$ & $81 \mathrm{bc}$ & $41 \mathrm{bc}$ & $121 \mathrm{~b}$ \\
4 & $21 \mathrm{~b}$ & $84 \mathrm{~b}$ & $11 \mathrm{de}$ & $96 \mathrm{bc}$ \\
5 & $23 \mathrm{a}$ & $84 \mathrm{~b}$ & $22 \mathrm{~cd}$ & $106 \mathrm{bc}$ \\
7 & $23 \mathrm{a}$ & $83 \mathrm{~b}$ & $42 \mathrm{~b}$ & $125 \mathrm{~b}$ \\
8 & $20 \mathrm{bc}$ & $78 \mathrm{bcd}$ & $28 \mathrm{bcd}$ & $105 \mathrm{bc}$ \\
9 & $24 \mathrm{a}$ & $96 \mathrm{a}$ & $17 \mathrm{de}$ & $113 \mathrm{~b}$ \\
10 & $23 \mathrm{a}$ & $77 \mathrm{~cd}$ & $89 \mathrm{a}$ & $166 \mathrm{a}$ \\
11 & $19 \mathrm{~cd}$ & $72 \mathrm{~d}$ & $10 \mathrm{de}$ & $82 \mathrm{C}$ \\
2 & $14 \mathrm{e}$ & $42 \mathrm{e}$ & $5 \mathrm{e}$ & $42 \mathrm{~d}$ \\
6 & $14 \mathrm{e}$ & $46 \mathrm{e}$ & $6 \mathrm{e}$ & $46 \mathrm{~d}$ \\
\hline C.V. & $13 \%$ & $14 \%$ & $40 \%$ & $40 \%$ \\
\hline
\end{tabular}

* Médias seguidas pela mesma letra, na coluna, não diferem entre si ao nível de 5\% de probabilidade, pelo teste de Tukey.

Em relação ao comprimento do bico, os isolados 1 e 10 formam o grupo de bico nitidamente mais longo, seguido de 
dois grupos de bico menor, o primeiro formado por 3, 7 e 8, e o segundo 4, 9 e 11; o isolado 5 possui bico de comprimento intermediário entre os isolados 4 e 8 . No último grupo encontram-se os isolados 2 e 6 que praticamente não possuem bico. O comprimento total do esporo tem alta correlação (93\%) com o comprimento do bico, ficando, então, o agrupamento quase que da mesma maneira: isolados 1 e 10, isolados 3, 7 e 9, isolados 4, 5 e 8, e isolado 11; o grupo de menor comprimento novamente é o dos isolados 2 e 6 .

O número de septos do corpo do esporo também foi anotado e analisado, variando de 3 a 12; os isolados ficaram assim distribuidos: 10,3 e $1 ; 4,5,7$ e $8 ; 10$ e $11 ; 2$ e 6

Esses resultados obtidos demonstram a dificuldade que existe em se classificar o fungo Alternaria a nivel de espécie, pois os isolados são agrupados de maneiras diferentes, dependendo da caraceristica enfocada, confirmando a constatação feita por diversos autores.

Alguns critérios morfológicos parecem ser mais importantes que outros. Segundo Rotem (1994), as dimensões do corpo do esporo, incluindo o bico, são consideradas as mais importantes características de uma espécie; o comprimento total do corpo do esporo parece ser mais 
relevante que sua largura, que é semelhante para a maioria das espécies. Entretanto, essa diferenciação não é muito clara ou mesmo fácil, pois em muitos casos há sobreposição do comprimento do esporo de espécies diferentes, como se pode constatar na Figura 2.

Por esses fatos verifica-se que há necessidade de se utilizar, além das medidas, outras observações que conjuntamente auxiliem na identificação de Alternaria a nível de espécie. Mesmo que comprimento do corpo do esporo seja mais importante que largura (Figura 3) ou comprimento do bico, estas últimas características podem auxiliar na separação, quando as diferenças são evidentes.

No presente estudo pode-se observar, em microscópio composto, que os esporos de alguns isolados, não pertencentes à espécie $A$. alternata, apresentam características de formato diferentes, podendo ser reunidos em dois grupos distintos. Os isolados 1 e 3 (Figura 4) apresentam esporos mais afilados, lisos, praticamente não havendo constrição nos septos ; o bico é consistentemente longo e sua transição do corpo do esporo é suave. Os demais 


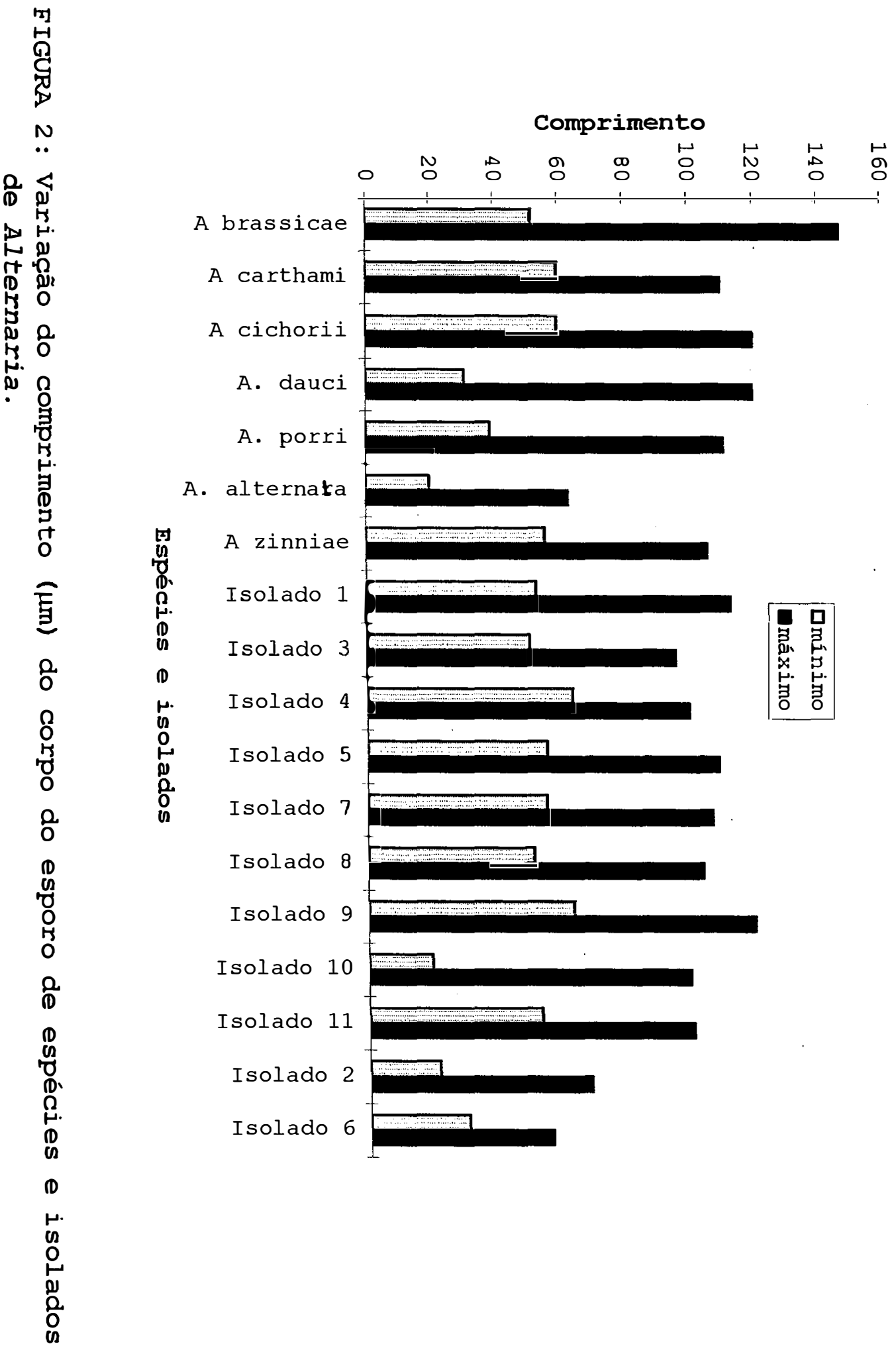




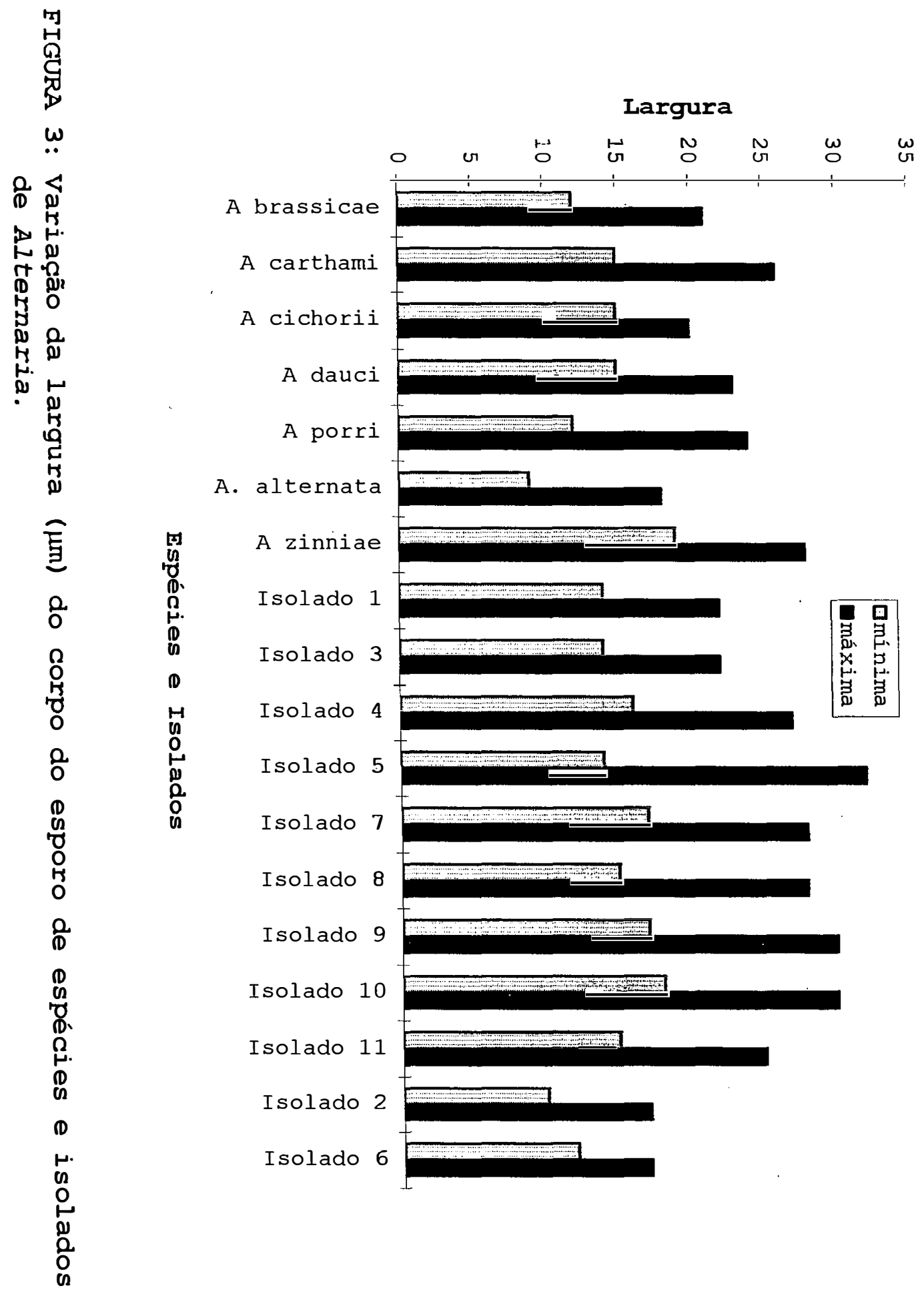




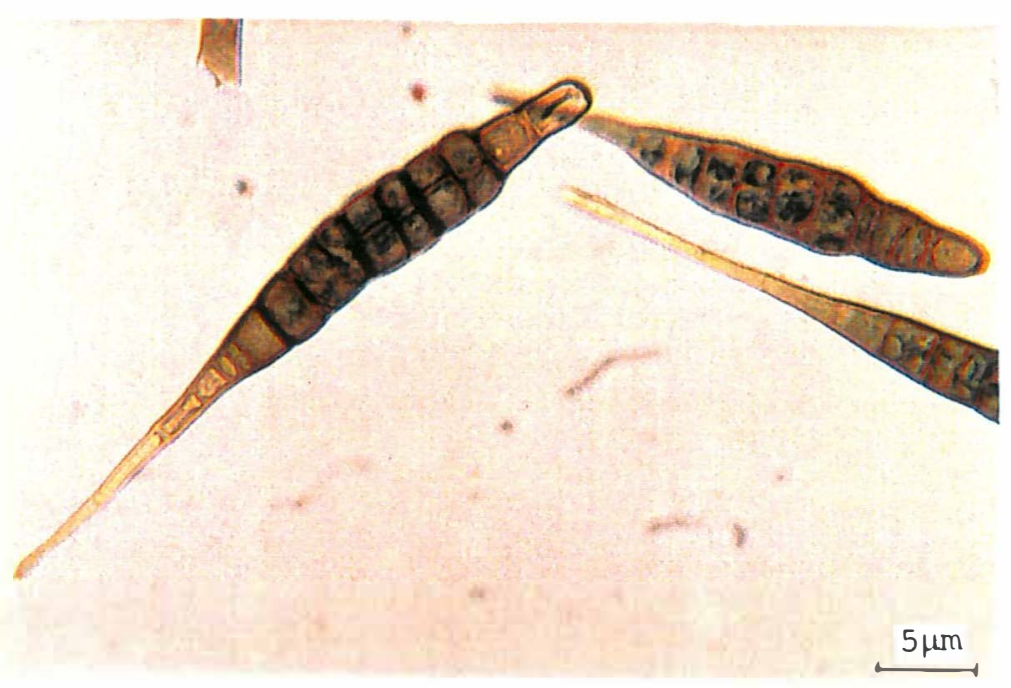

Isolado 1

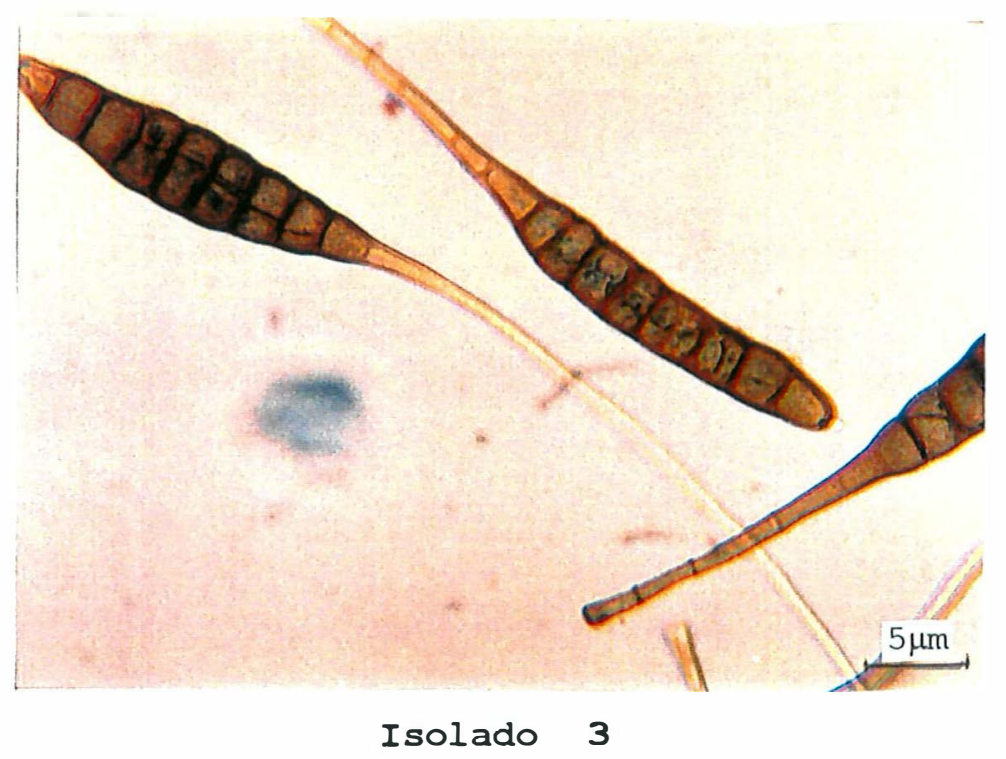

FIGURA 4: Esporos dos isolados 1 e 3 da espécie Alternaria cichorii, observados em microscópio composto em aumento de $400 x$. 
isolados, de esporos não catenulados, possuem corpo do esporo mais largo (Figuras 5, 6 e 7) com septos mais marcados e frequentemente constritos; a transição do corpo do esporo para o bico é abrupta e este é, geralmente, curto. Dentro deste último grupo, os isolados 7 e 10 possuem uma variação muito grande entre seus esporos, porém as caracteriaticas mais constantes os incluem neste grupo.

Pelas dificuldades encontradas, procurou-se o auxílio de outras instituições como a Universidade Federal de Pernambuco e Centraalbureau voor Shimmelcultures / Dinamarca, para ajudar na identificação. No caso dos isolados 1 e 2, as informações da Universidade Federal de Pernambuco foram de grande auxílio. A instituição da Dinamarca avaliou todos os isolados em estudo, porém a identificação não trouxe muita contribuição, pois alguns isolados não produziram esporos e o pesquisador deu ciência que, sem informação de hospedeiro e sintomas, nenhuma identificação apropriada seria possível.

Comparando esses resultados com a literatura mais completa sobre este assunto (Ellis, 1971 e 1976, e Rotem, 1994), sugere-se que os isolados 1 e 3 sejam denominados de A. Cichorii e os isolados 4, 5, 7, 8, 9, 10 e 11 de $A$. carthami. Alguns autores denominam o agente causal da 

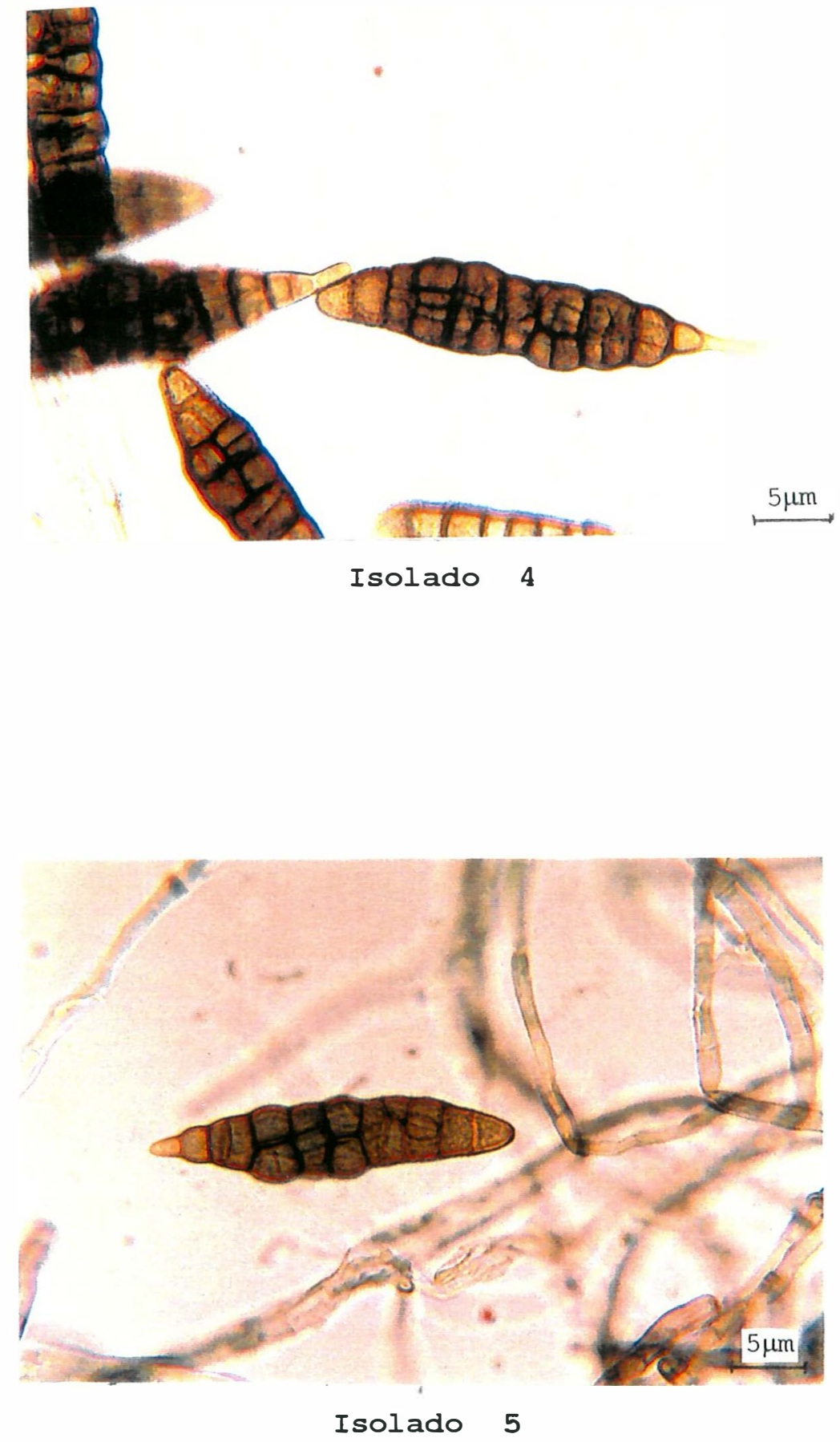

FIGURA 5: Esporos dos isolados 4 e 5 da espécie Alternaria carthami, observados em microscópio composto em aumento de $400 x$. 

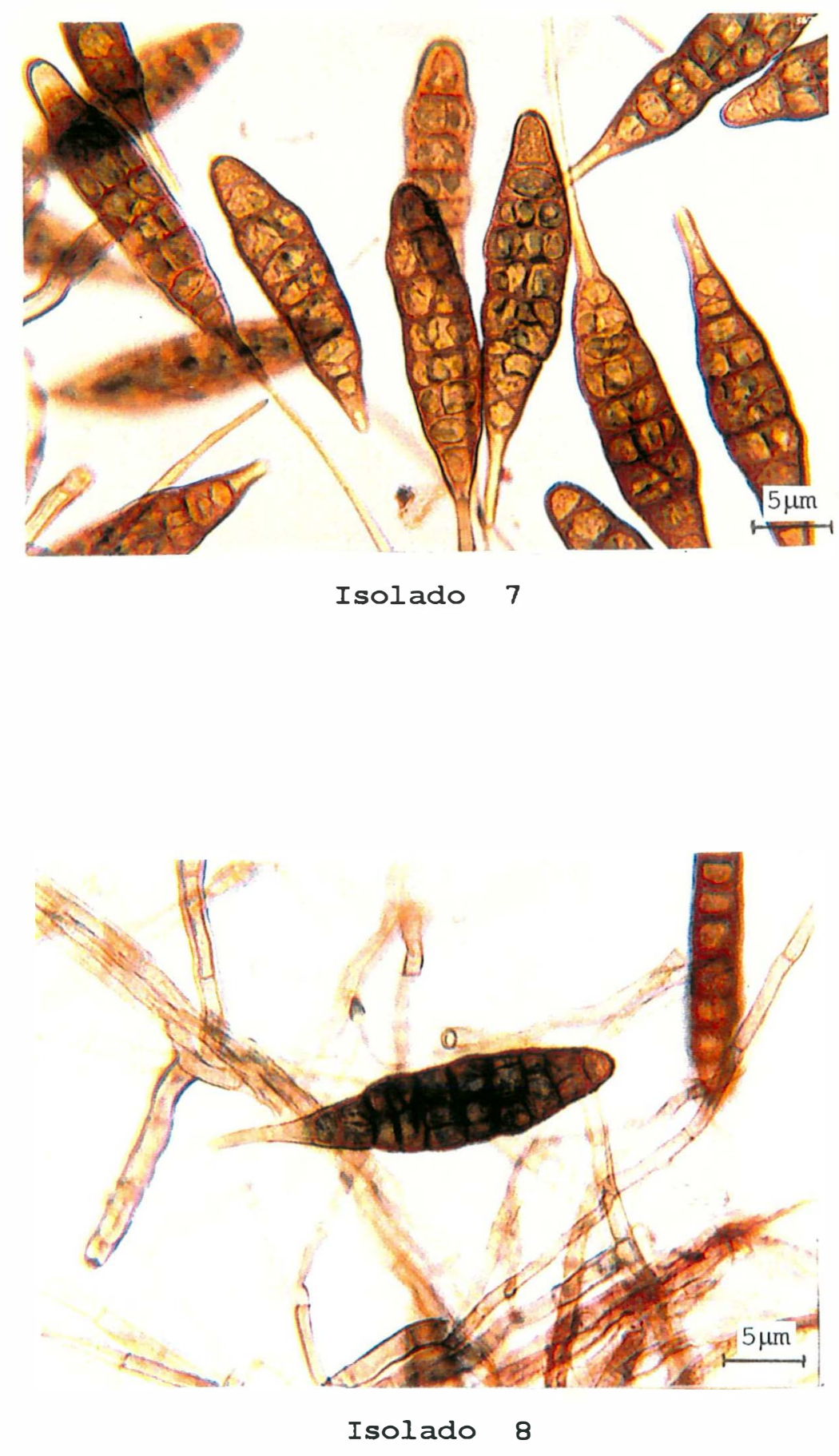

FIGURA 6: Esporos dos isolados 7 e 8 da espécie Alternaria carthami, observados em microscópio composto em aumento de $400 x$. 

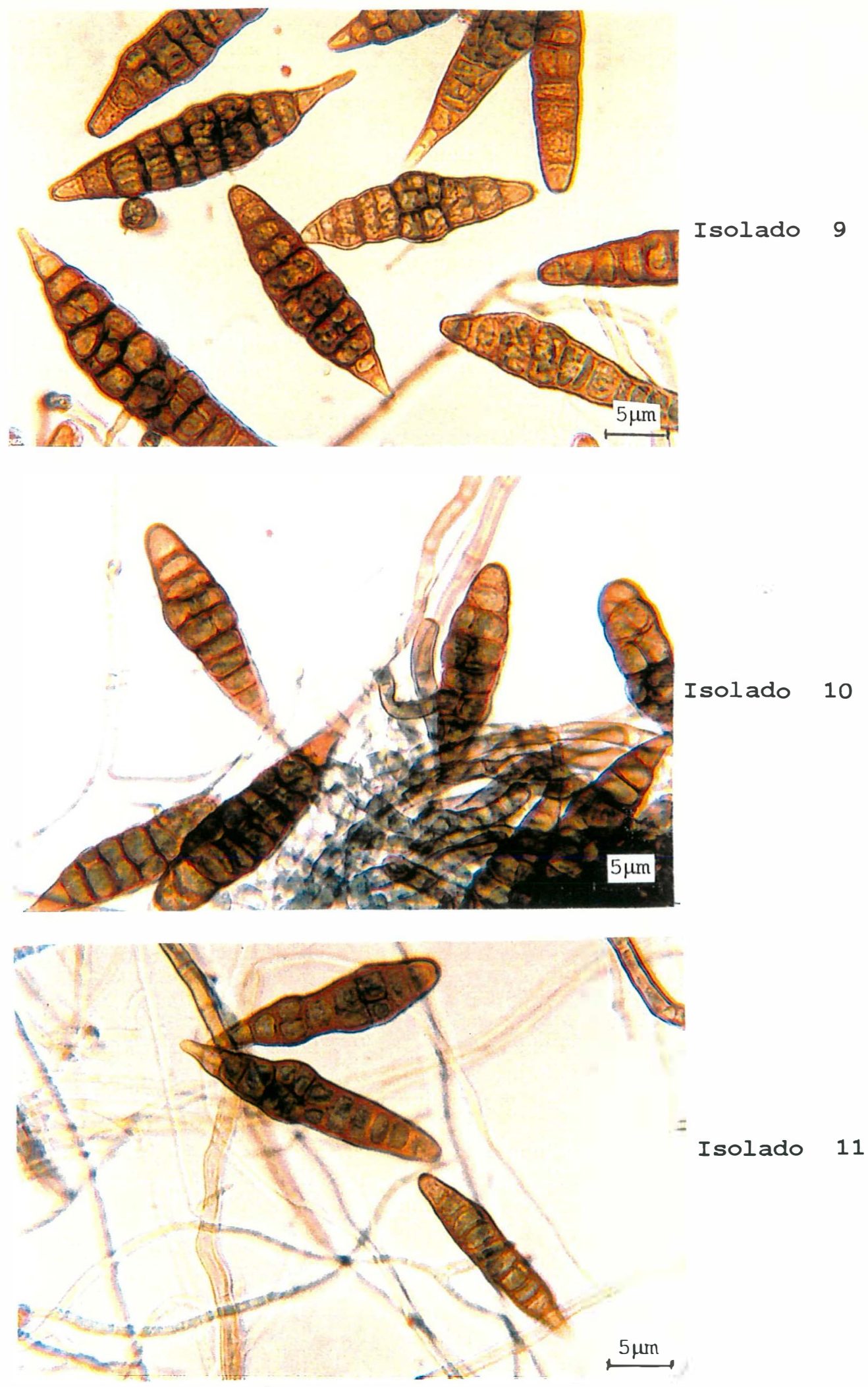

FIGURA 7: Esporos dos isolados 9, 10 e 11 da espécie Alternaria carthami, observados em microscópio composto em aumento de $400 x$. 
mancha de Alternária do feijoeiro de Alternaria brassicae, outros de $A$. zinniae, porém os resultados obtidos com este trabalho não levaram à concordância com estes autores. A. brassicae, pelo observado na literatura, possue corpo do esporo mais longo e mais fino que dos isolados estudados, tem poucos septos longitudinais não constritos e bico bastante curto; por outro lado $A$. zinniae se assemelha mais a estes isolados, porém o corpo do esporo é mais largo. Das espécies analisadas por eletroforese, A. porri e A. dauci mostraram alguma semelhança com os isolados de A. carthami porém, diferiram quanto às características morfológicas . Pelos resultados obtidos confirmou-se que os isolados 2 è 6 pertencem à espécie Alternaria alternata (Figura 8).

\subsubsection{Caracterização cultural}

Através da observação das colônias dos isolados, produzidas em meio de cultura de BDA e de tomate, verificaram-se diferentes tipos ; o meio de tomate aumentou a esporulação de todos isolados, porém as características culturais foram melhor observadas em BDA e são descritas a seguir: 

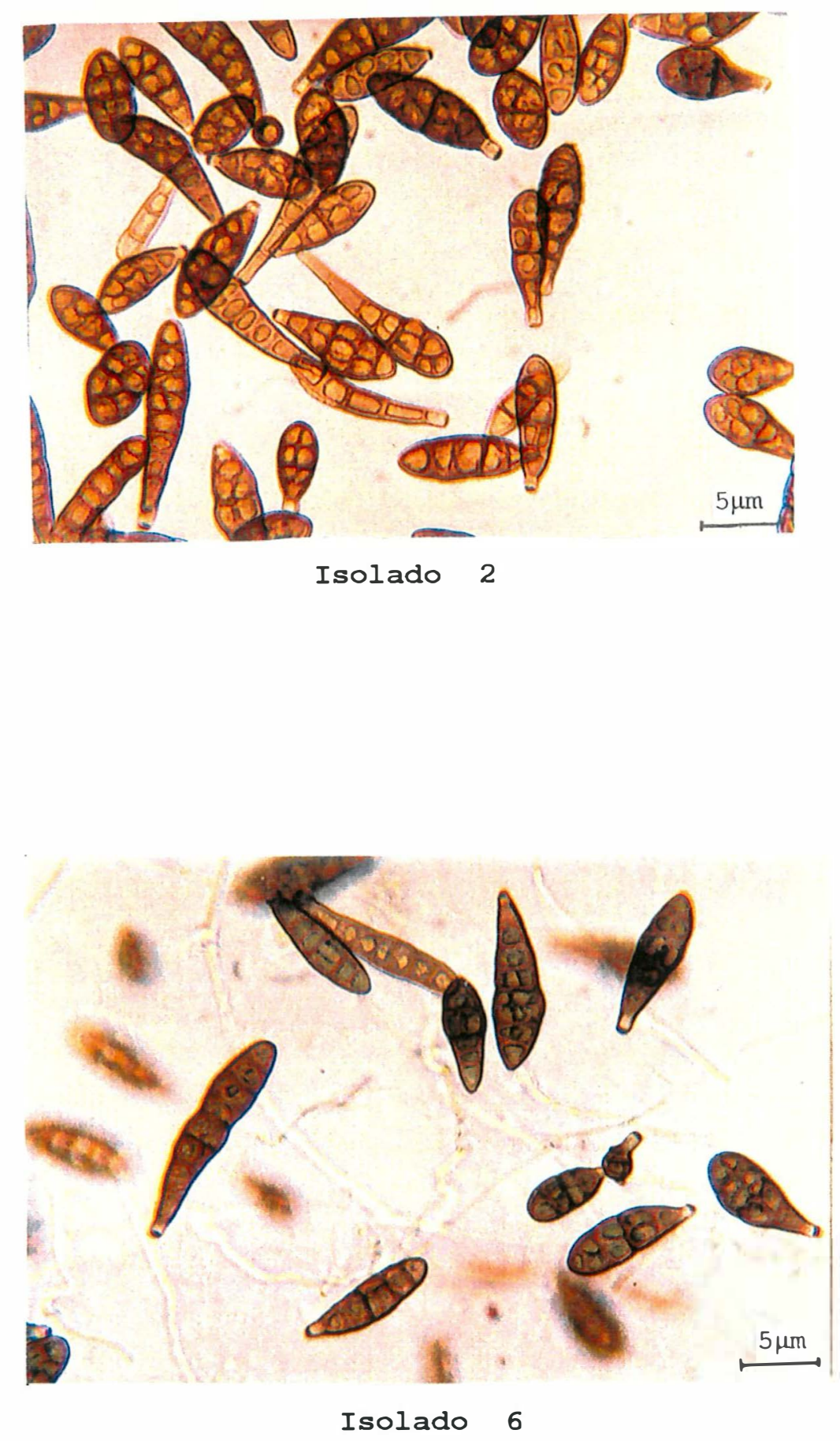

FIGURA 8: Esporos dos isolados 2 e 6 da espécie Alternaria alternata, observados em microscópio composto em aumento de $400 x$. 
- colônias formando zonas concêntricas nítidas, com pouco crescimento micelial aéreo e esporulação intermediária; aqui se enquadram os isolados 1, 4, 7 e 9, que não produzem coloração amarelada no meio de cultura;

- colônias formando zonas concêntricas nítidas, com pouco crescimento micelial aéreo, esporulação intermediária e coloração amarelada no meio de cultura; os isolados 5 e 11 pertencem a este grupo;

- colônias formando zonas concêntricas não muito nítidas, com crescimento micelial aéreo abundante e difícil esporulação; os isolados 3 e 8 estão neste grupo, sendo que o primeiro produz coloração no meio;

- colônias de crescimento radial anômalo, quase não ocorrendo formação de zonas concêntricas, com crescimento micelial aéreo, esporulação intermediária e coloração no meio, são produzidas pelo isolado 10;

- colônias formando zonas concêntricas acentuadas, com pouco crescimento micelial aéreo e esporulação abundante; isolados 2 e 6 .

Essas características, que foram observadas no meio de cultura, não auxiliaram na identificação ou agrupamento dos isolados, pois nem sempre os que são considerados morfologicamente semelhantes produzem colônias com as mesmas características. Têm-se como exemplo os isolados 1 e 
3, da espécie Alternaria cichorii, onde o segundo isolado é de difícil esporulação e produz coloração amarelada no meio de cultura, diferentemente do primeiro. Os isolados 4 e 5 são outro exemplo, sendo que estes se diferenciam porque 0 isolado 4 não produz coloração no meio.

\subsubsection{Caracterização eletroforética dos isolados de Alternaria spp.}

$\mathrm{Na}$ Figura 9, pode-se observar o diagrama correspondente aos perfis eletroforéticos de esterase, extraída dos isolados de Alternaria spp. de feijão.

Analisando o número, posição e intensidade das bandas eletroforéticas, verifica-se que os isolados pertencentes à espécie $A$. carthami, com exceção do número 5, possuem mobilidade relativa (Rm) bastante próximas, indo de 2,4 a 3,7 para os isolados 4, 7, 8 e 9, e 2,0 a 4,2 para o 10 e de 3,3 a 4,1 para o isolado 11; a banda de maior intensidade para o isolado 5 apresentou $\mathrm{Rm}$ entre 0,2 a 2,0. Além dessa banda de maior intensidade, a maioria dos isolados de $A$. carthami apresentou outras duas bandas de 

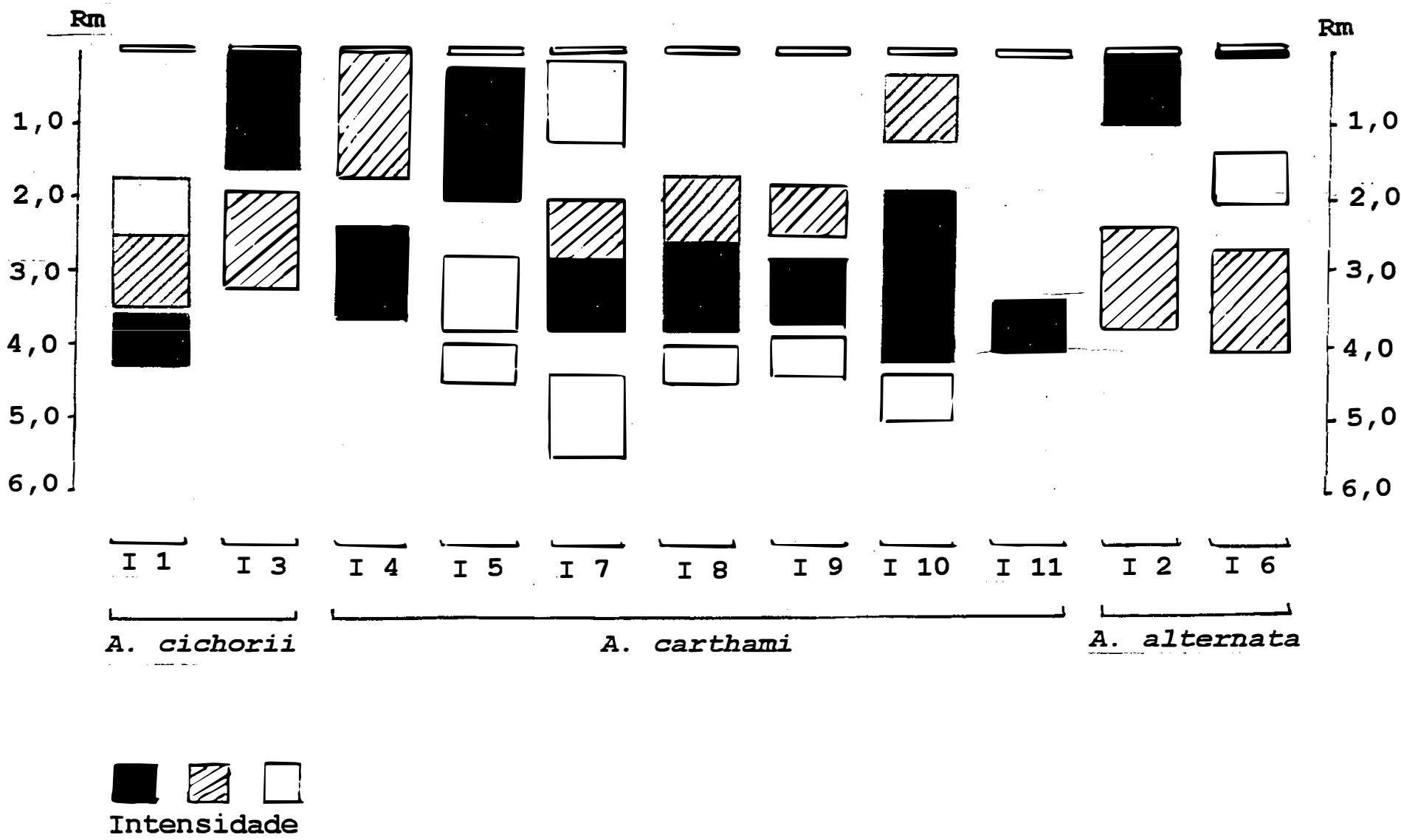

FIGURA 9: Diagrama dos perfis eletroforéticos de esterase e mobilidade relativa (Rm) de isolados morfologicamente semelhantes às espécies Alternaria cichorii, A. carthami e A. alternata. 


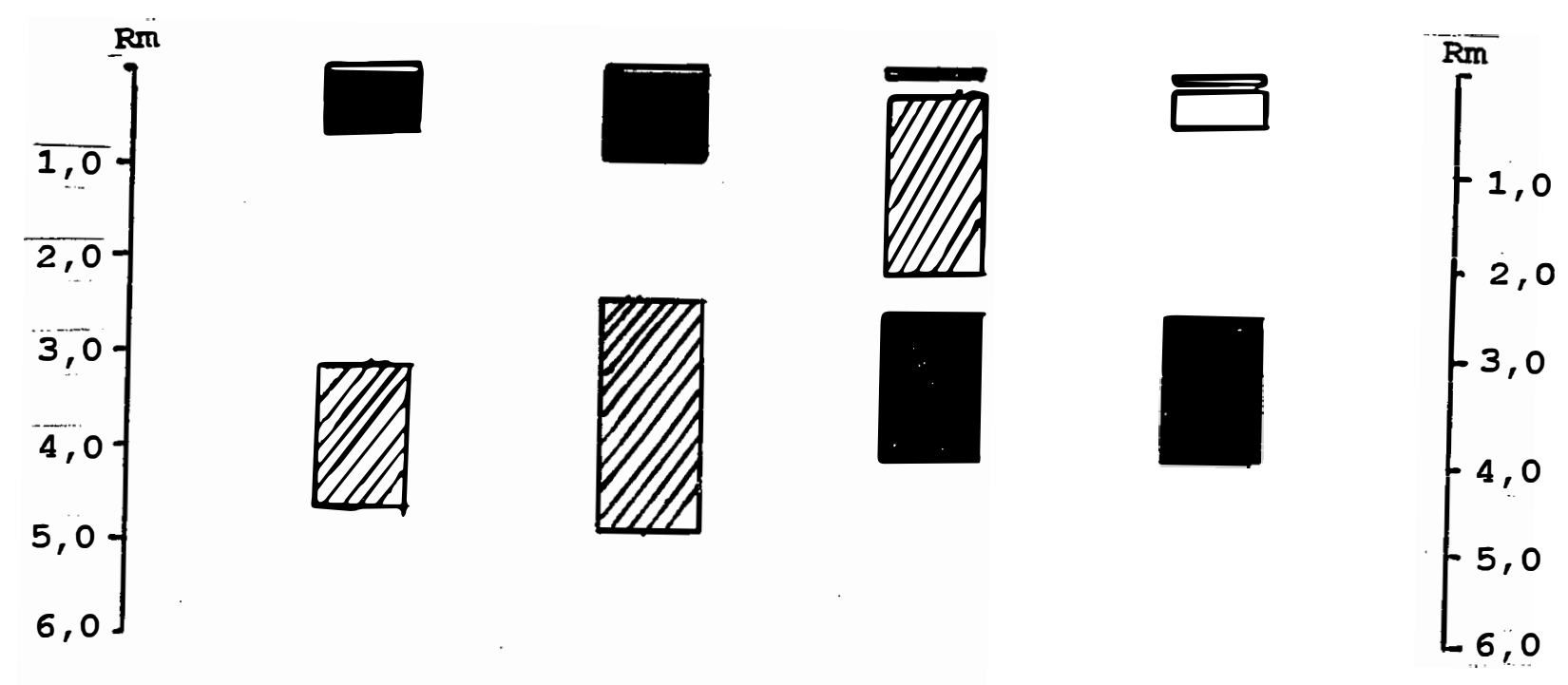

A. brassicae A. cucumerina A. dauci A. porri

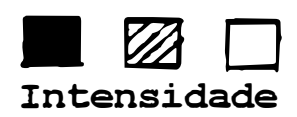

FIGURA 10: Diagrama dos perfis eletroforéticos de esterase e mobilidade relativa (Rm) de isolados de Alternaria brassicae, $A$. cucumerina, A. dauci e A. porri. 
intensidade média e baixa, sendo exceções o isolado 4 que apresentou apenas uma a mais, o 11 que não apresentou nenhuma e $\circ 7$ que apresentou um total de quatro bandas, sendo uma de maior intensidade, uma de intensidade média e duas de baixa intensidade.

Os dois isolados pertencentes à espécie $A$. cichorii não mostraram um perfil eletroforético semelhante; o isolado 1 apresentou formação de três bandas de intensidades diferentes, sendo que a de maior intensidade possui Rm entre 3,5 e 4,5, enquanto que $\circ 3$ apresentou duas bandas e a de maior intensidade com Rm entre 0 e 1,7.

Para os isolados 2 e 6 de Alternaria alternata verifica-se a semelhança entre eles através das bandas de intensidade intermediária, que possuem $\mathrm{Rm}$ entre 1,1 e 2,0 para o isolado 2, e Rm emtre 1,4 e 2,0 para o 6; a banda de maior intensidade inicia na mesma posição, mas a do isolado 6 tem menor mobilidade relativa.

$\mathrm{Na}$ Figura 10 verifica-se a representação da densitometria do padrão de esterase destes isolados, cujo número, tamanho e posição dos picos comparados reforçam as observações descritas nos perfis eletroforéticos.

Analisando esses resultados confirma-se 0 agrupamento, realizado através de características morfológicas, dos isolados 4, 7, 8, 9, 10 e 11, e dos 


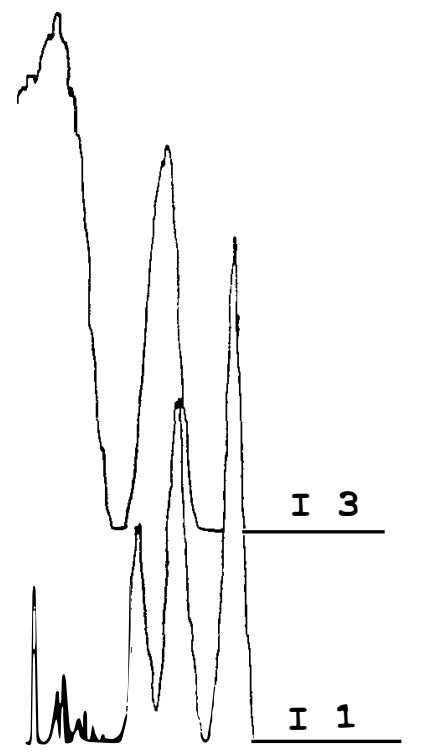

A. cichorii

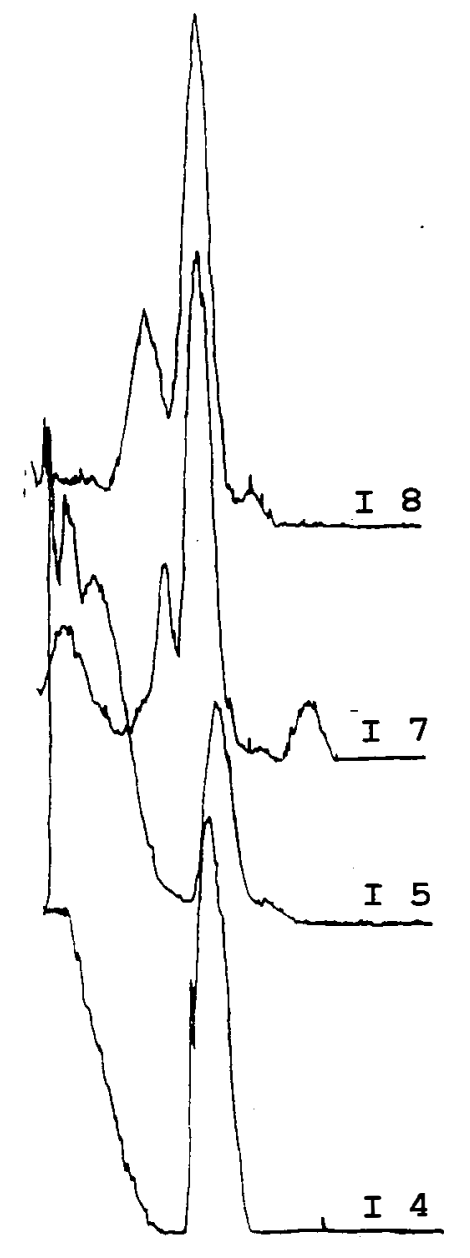

A. carthami
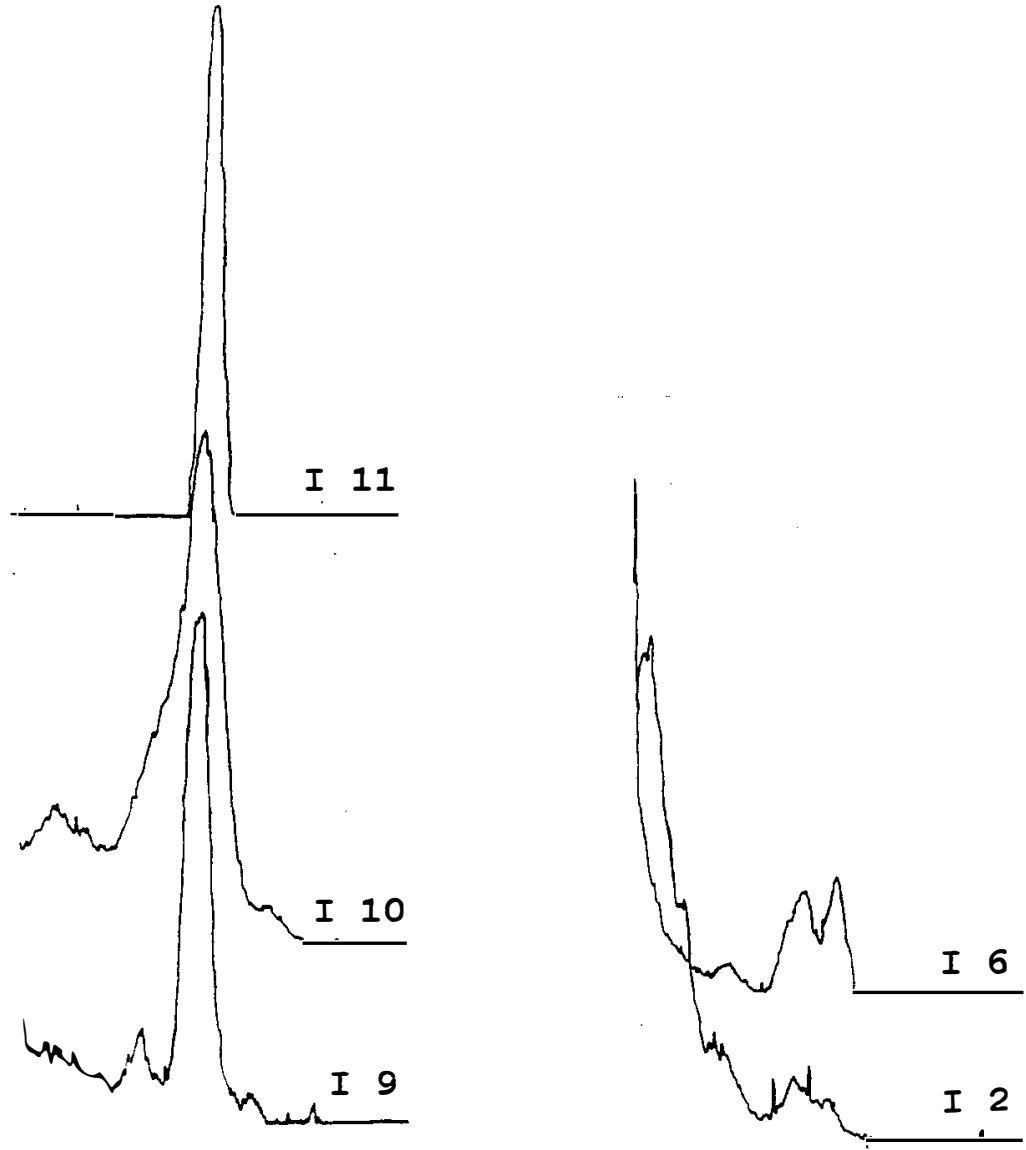

A. alternata

FIGURA 11: Diagrama densitométrico (540 nm) do padrão de esterase de isolados de Alternaria cichorii, A. carthami e A. alternata. 


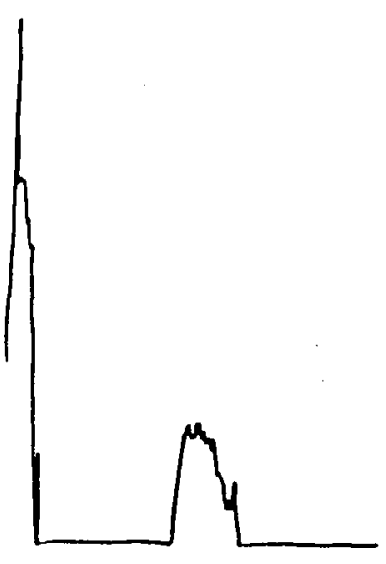

A. brassicae

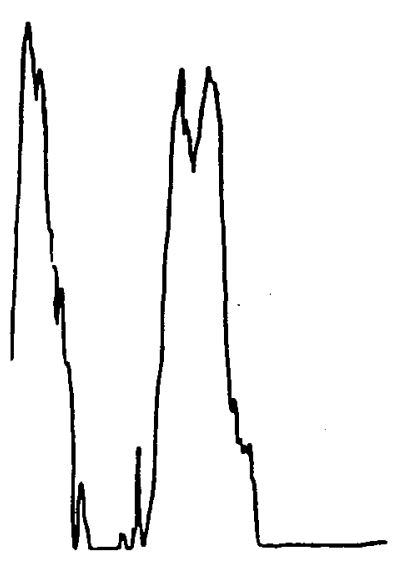

A. cucumerina

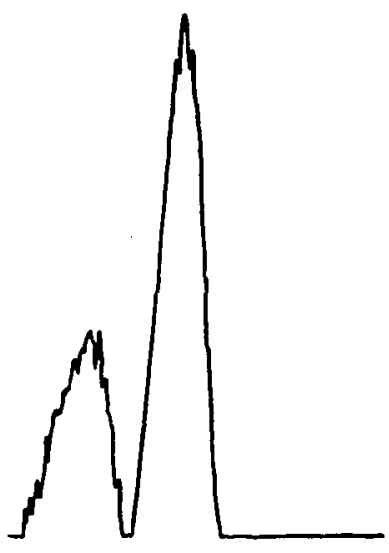

A. dauci

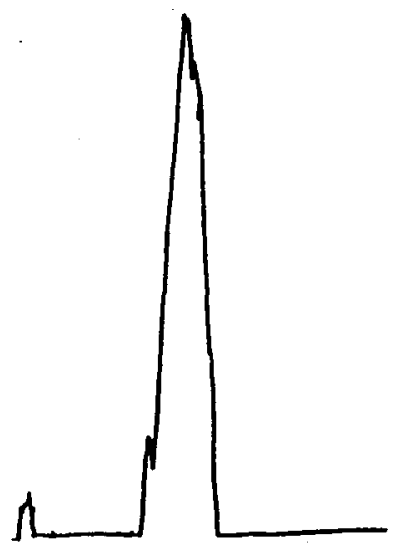

A. porri

FIGURA 12: Diagrama densitométrico (540nm) do padrão de esterase dos isolados de Alternaria brassicae, A. cucmerina, A. dauci e $A$. porri.

๙ 
isolados 2 e 6 . Observa-se claramente que os isolados 1 e 3, considerados pertencentes à espécie $A$. cichorii, não se enquadram nestes grupos, mas também não possuem padrões eletroforéticos semelhantes. O 5, apesar da grande semelhança morfológica com os demais do seu grupo, não apresentou padrão eletroforético semelhante.

Essa variação eletroforética entre isolados existe, como pode ser constatado na literatura. Petrunak \& Christ (1992) analisando vários isolados de Alternaria solani e de A. alternata, observaram alta variabilidade isozímica entre os isolados, detectando 35 tipos eletroforéticos. Estes autores comentam que uma explicação para esse nível de variação pode ser a mutação natural; $A$. solani e $A$. alternata são capazes de produzir um grande número de esporos em curto espaço de tempo, e isso combinado com a taxa de mutação natural, pode levar a um nível relativamente alto de diversidade.

\subsubsection{Desenvolvimento de colônias de isolados de Alternaria spp. sob diferentes temperaturas}

Este experimento demonstrou que a melhor temperatura para crescimento in vitro (Tabela 8), para a média dos ișolados de Alternaria spp., foi $25^{\circ} \mathrm{C}$. 
TABELA 8: Diâmetro* médio (cm) das colônias de isolados de Alternaria spp. submetidas a diferentes temperaturas

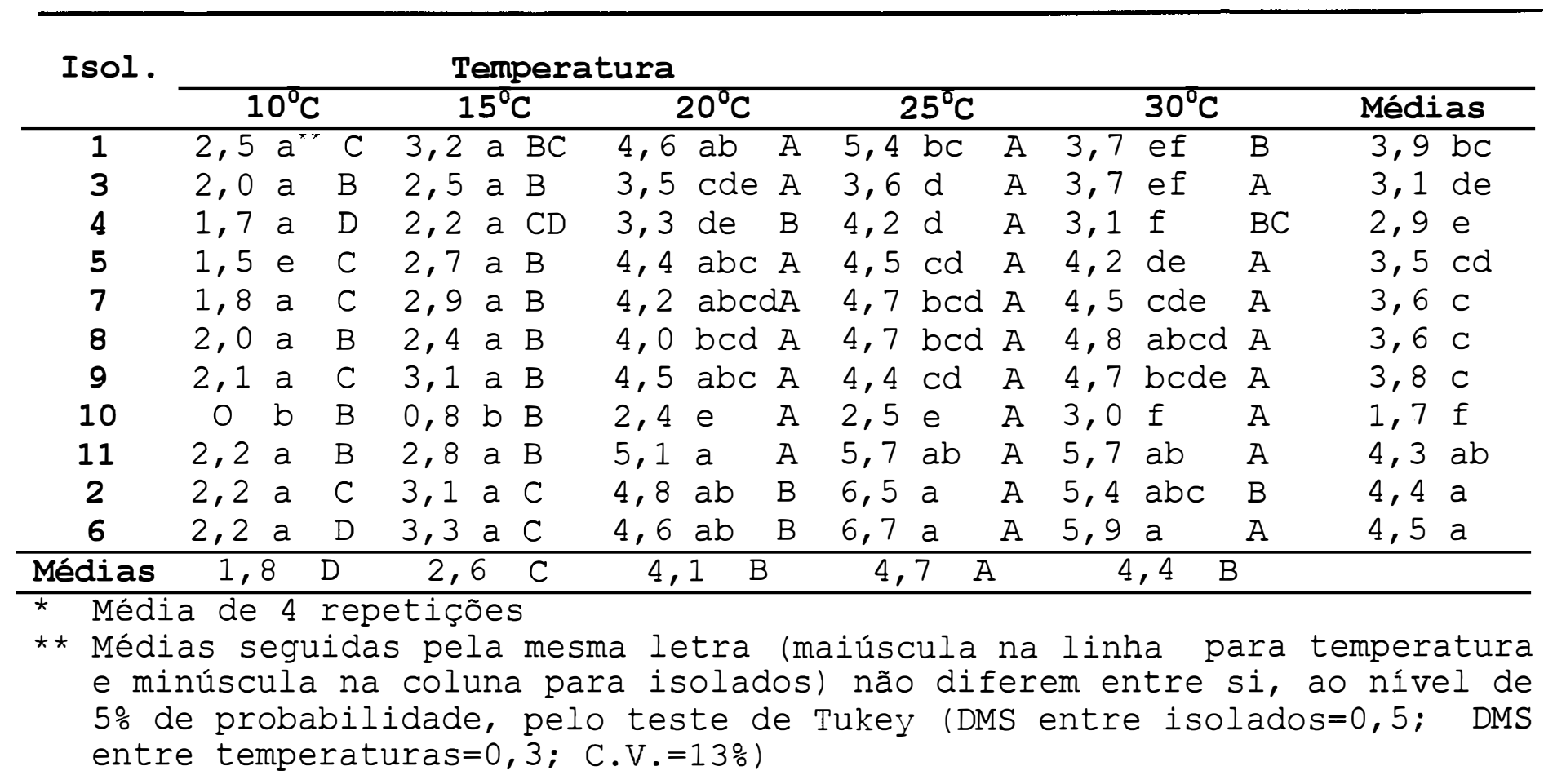


Estes resultados estão de acordo com aqueles encontrados em literatura. Saad e Hagedorn (1970) obtiveram melhor crescimento a $28^{\circ} \mathrm{C}$ para Alternaria alternata, enquanto que para $A$. solani o maior desenvolvimento foi a $25^{\circ} \mathrm{C}$, segundo Fancelli (1991). Para Pound (1951), isolados de $A$. solani apresentaram crescimento ótimo em temperaturas que variam de $25^{\circ}$ a $28^{\circ} \mathrm{C}$.

Pela análise estatística dos resultados, constatou-se a interação altamente significativa entre isolados e temperaturas; todos os isolados desenvolveram-se bem na temperatura de $25^{\circ} \mathrm{C}$, porém a partir desta temperatura alguns tiveram seu desenvolvimento diminuido e outros o mantiveram ou aumentaram na temperatura de $30^{\circ} \mathrm{C}$. Na Tabela 9 observa-se a temperatura na qual o isolado pode atingir seu desenvolvimento máximo, temperatura esta obtida através de análise da regressão polinomial dos dados.

Para os isolados 1 e 4 a melhor temperatura para seu desenvolvimento foi entre $20^{\circ}$ e $25^{\circ} \mathrm{C}$; já os isolados 2, 5, 7, 9 e 11 desenvolveram-se melhor entre $25^{\circ}$ e $30^{\circ} \mathrm{C}$ enquanto que os isolados 8,10 e 6 , acima de $30^{\circ} \mathrm{C}$. 
Tabela 9. Equação da regressão polinomial para temperatura de crescimento máximo para os isolados de Alternaria spp.

\begin{tabular}{|c|c|c|c|}
\hline Isolados & & Equação* & $\mathrm{T}^{0}$ de cresc. máximo \\
\hline 1 & $y=-3,36$ & $+0,71 x-0,016 x^{2}$ & $22,3^{\circ} \mathrm{C}$ \\
\hline 3 & $y=-0,47$ & $+0,28 x-0,005 x^{2}$ & $28,3^{\circ} \mathrm{C}$ \\
\hline 4 & $y=-2,32$ & $+0,48 x-0,010 x^{2}$ & $23,8^{\circ} \mathrm{C}$ \\
\hline 5 & $y=-4,11$ & $+0,68 x-0,013 x^{2}$ & $26,0^{\circ} \mathrm{C}$ \\
\hline 7 & $y=-2,51$ & $+0,52 x-0,009 x^{2}$ & $28,7^{\circ} \mathrm{C}$ \\
\hline 8 & $y=-1,03$ & $+0,32 x-0,004 x^{2}$ & $39,8^{\circ} \mathrm{C}$ \\
\hline 9 & $y=-1,80$ & $+0,46 x-0,008 x^{2}$ & $29,1^{\circ} \mathrm{C}$ \\
\hline 10 & $y=-3,34$ & $+0,38 x-0,006 x^{2}$ & $31,7^{\circ} \mathrm{C}$ \\
\hline 11 & $y=-2,62$ & $+0,54 x-0,009 x^{2}$ & $29,9^{\circ} \mathrm{C}$ \\
\hline 2 & $y=-3,67$ & $+0,68 x-0,010 x^{2}$ & $27,8^{\circ} \mathrm{C}$ \\
\hline 6 & $y=-2,70$ & $+0,55 x-0,008 x^{2}$ & $34,4^{\circ} \mathrm{C}$ \\
\hline
\end{tabular}

Verifica-se que, através da temperatura, não foi possível confirmar o agrupamento dos isolados em termos de morfologia ou patogenicidade, pois alguns de uma mesma espécie têm temperaturas diferentes para seu melhor desenvolvimento. Por exemplo, isolados 8 e 10, da espécie A. carthami, que se desenvolvem bem sob temperaturas mais altas que $30^{\circ} \mathrm{C}$, mas que possuem graus de virulência diferentes.

Este dados obtidos, principalmente através da caracterização morfológica e eletroforética, permitem concluir que os isolados 1 e 3 pertencem a uma determinada espécie, os de número 4, 5, 7, 8, 9, 10 e 11, a outra 
diferente espécie e, por fim, os isolados 2 e 6 , a outra. A exaustiva comparação dos resultados com a literatura especializada, levou à conclusão de que os primeiros isolados são morfologicamente semelhantes a Alternaria Cichorii e o segundo grupo a A. carthami. Os isolados 2 e 6 podem ser confirmados como pertencente à espécie $A$. alternata.

Seria sumamente importante que houvessem isolados dessas espécies que pudessem ser utilizados como padrões para comparação tanto a nível de morfologia quanto de análise eletroforética. Como não foi possível a realização dessa comparação neste trabalho, devido à impossibilidade de se obter isolados de A. cichorii e A. carthami, fica a sugestão para trabalhos posteriores.

\subsection{Reação de cultivares de feijoeiro a diferentes isolados de Alternaria spp.}

\subsubsection{Número de lesões por área foliar}

Através do componente monocíclico de resistência frequência de infecção, dado pelo número de lesões por área foliar (Tabela 10), verifica-se que os cultivares testados 
TABELA 10: Número de lesões* causadas por isolados de Alternaria spp. en plantas de feijoeiro.

\begin{tabular}{|c|c|c|c|c|c|c|c|c|c|c|c|c|}
\hline Cultivares & 1 & 3 & 4 & 5 & 7 & 8 & 9 & 10 & 11 & 2 & 6 & M \\
\hline IAPAR 44 & 8.6 & 0 & 19.4 & 14.6 & 15.6 & 35.9 & 18.2 & 9.9 & 13.4 & 0 & 0 & $9.5 \mathrm{a}^{* *}$ \\
\hline Roxo-90 & 4.8 & 0 & 19.3 & 5.2 & 17.3 & 38.8 & 28.0 & 3.2 & 12.8 & 0.1 & 0 & $8.3 \mathrm{ab}$ \\
\hline Aporé & $6.8^{*}$ & 0 & 36.0 & 15.6 & 8.9 & 35.0 & 20.0 & 1.1 & 4.1 & 0.2 & 0 & $8.0 \mathrm{abc}$ \\
\hline Carioca & 4.5 & 0 & 9.8 & 11.7 & 14.7 & 19.8 & 24.6 & 7.4 & 8.0 & 0.3 & 0 & $7.1 \mathrm{abcd}$ \\
\hline IAPAR 57 & 5.3 & 0 & 12.6 & 2.6 & 16.4 & 19.2 & 17.0 & 1.8 & 28.7 & 0.1 & 0 & $6.8 \mathrm{bcd}$ \\
\hline Rosinha & 4.9 & 0 & 15.6 & 24.5 & 3.4 & 19.2 & 16.6 & 1.4 & 11.6 & 0 & 0 & 6.4 bcde \\
\hline IAPAR 14 & 4.6 & 0 & 7.2 & 9.3 & 13.1 & 29.6 & 11.7 & 1.3 & 16.2 & 0.1 & 0 & 6.2 bcde \\
\hline MD-821 & 1.7 & 0 & 8.3 & 2.4 & 10.9 & 29.6 & 18.2 & 3.2 & 16.6 & 0.1 & 0 & $5.8 \mathrm{cde}$ \\
\hline R. Tibagi & 3.1 & 0 & 8.2 & 0.5 & 6.1 & 30.3 & 15.7 & 3.3 & 10.5 & 0.1 & 0 & $4.8 \mathrm{def}$ \\
\hline IAC-Cari. & 2.1 & 0 & 9.5 & 0.7 & 2.2 & 15.7 & 16.4 & 6.3 & 11.6 & 0 & 0 & $4.2 \mathrm{efg}$ \\
\hline Jalo Prec. & 0 & 0 & 20.3 & 3.4 & 0.2 & 20.7 & 7.7 & 0 & 7.6 & 0.7 & 0 & $3.4 \mathrm{fgh}$ \\
\hline Novo Jalo & 0 & 0 & 12.8 & 0.2 & 0.2 & 14.8 & 9.0 & 0 & 31.4 & 0 & 0 & $3.3 \mathrm{fgh}$ \\
\hline C. Azul & 0.8 & 0 & 3.8 & 0.6 & 8.4 & 23.7 & 2.5 & 2.0 & 5.7 & 0.1 & 0 & $2.9 \mathrm{gh}$ \\
\hline Goia. Pre. & 0 & 0 & 5.4 & 1.4 & 0.1 & 17.9 & 6.9 & 0 & 9.8 & 0 & 0 & $2.3 \mathrm{~h}$ \\
\hline \multirow[t]{2}{*}{$\mathrm{M}$} & 2.8 & 0 & 12.4 & 5.0 & 6.9 & 24.4 & 14.3 & 2.4 & 12.5 & 0.1 & 0 & \\
\hline & $\mathrm{D}$ & $\mathrm{E}$ & $\mathrm{B}$ & $\mathrm{C}$ & $\mathrm{C}$ & $\mathrm{A}$ & B & $\mathrm{D}$ & $\mathrm{B}$ & $\mathrm{E}$ & $\mathrm{E}$ & \\
\hline $\begin{array}{ll}\text { * } & \text { Média } \\
\star & \text { Médias } \\
& \text { núscu } \\
\text { probak } & \text { entre }\end{array}$ & de 4 & & tiçõ & $5, n$ & mero & $\mathrm{de}$ & esões & por & $\begin{array}{l}25 \\
\text { ent } \\
\text { si, }\end{array}$ & $\mathrm{m}^{2}$ & & $\begin{array}{l}\text { a foliar } \\
\text { ss e mi- } \\
\text { de 5\% de } \\
0,4 ; \text { DMS }\end{array}$ \\
\hline
\end{tabular}


apresentam diferentes níveis de resistência para a média dos isolados, e que há interação altamente significativa entre hospedeiro e patógeno, indicando a existência de resistência vertical incompleta nesses materiais.

Os cultivares que se mostraram mais resistentes, pelo teste de Tukey, foram Goiano Precoce e Cerro Azul, enquanto que o mais suscetível foi IAPAR 44. Os demais apresentaram resistências intermediárias, sendo Roxo $90 \quad 0$ mais suscetível e Novo Jalo o mais resistente dentre estes.

A Figura 13, apresentando a quantificação da resistência vertical incompleta e resistência horizontal, mostra que a maior resistência dos cultivares Goiano Precoce e Cerro Azul é conferida, em sua maior parte, pela RVi, enquanto que IAC-Carioca possui maior quantidade de $\mathrm{RH}$ que os outros cultivares, adicionada de uma significativa RVi .

Os cultivares que se mostraram mais suscetíveis (IAPAR 44, Roxo-90 e Aporé), possuem baixa quantidade de RVi e RH ainda menor, explicando sua suscetibilidade.

\subsection{2. Área foliar afetada}

A porcentagem da área foliar afetada não é considerada um componente monocíclico de resistência a ser 

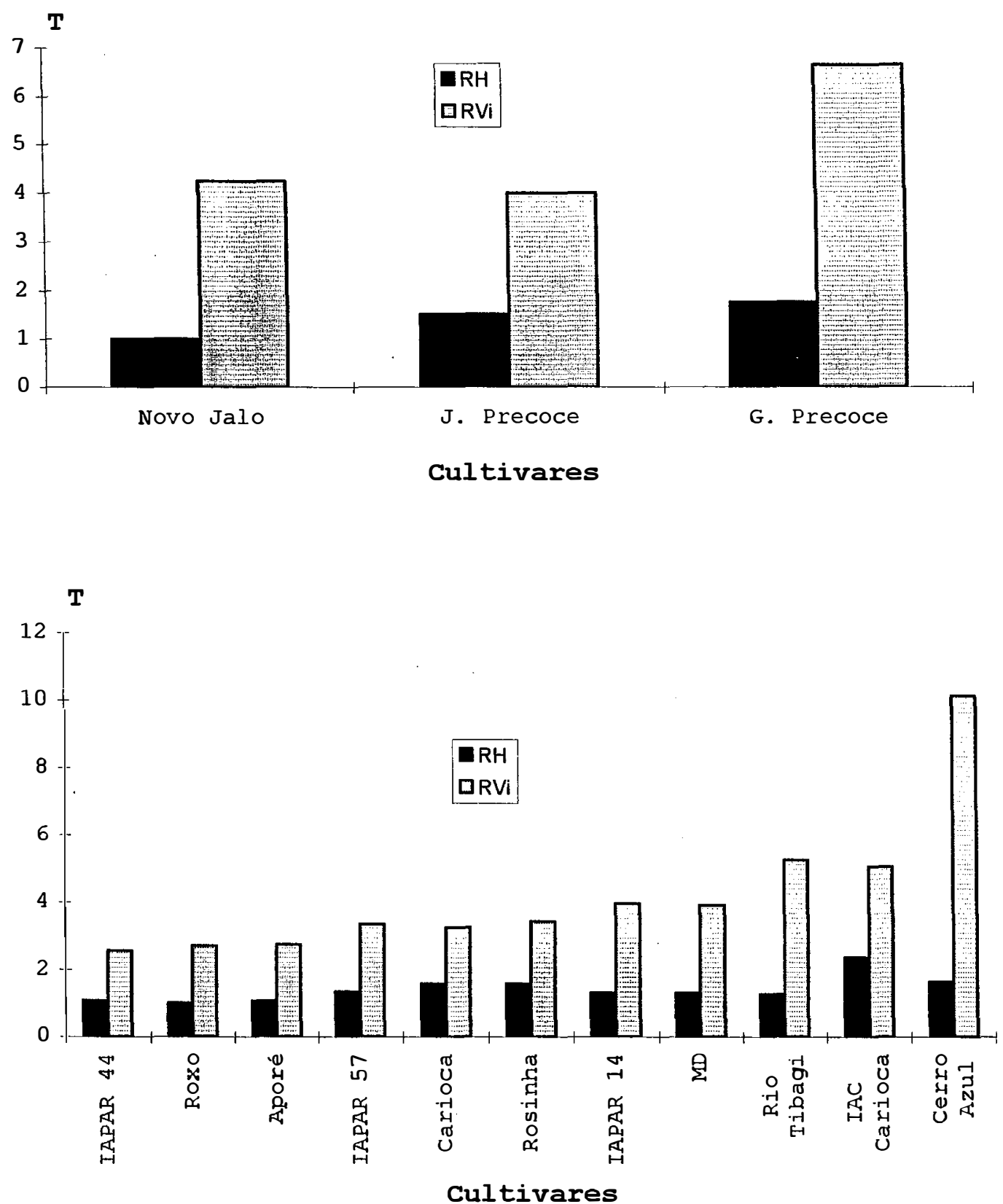

FIGURA 13: Quantificação de resistência horizontal e vertical incompleta em cultivares de feijoeiro para o parâmetro número de lesões. 
avaliado, porém é um método eficiente para quantificação da severidade da doença, podendo auxiliar na separação dos cultivares. Houve correlação positiva(82\%) entre o número de lesões e porcentagem de área foliar afetada, neste trabalho.

A Tabela 11 apresenta a diferença estatística entre as médias dos cultivares, indicando que dentre eles o mais resistente foi Goiano Precoce, enquanto que Carioca e IAPAR 44 mostraram-se mais suscetiveis. Os demais cultivares apresentaram resistência intermediária, indo do mais suscetível (Roxo 90) ao mais resistente (Jalo Precoce e Novo Jalo). Esses resultados confirmam aqueles obtidos para o parâmetro número de lesões.

Na Figura 14, que mostra a quantificação da resistência, pode-se observar que o cultivar IAC-Carioca possui maior quantidade de RH que os demais e alta RVi, como constatado para o parâmetro número de lesões; o Goiano Precoce, considerado o mais resistente pelo teste de Tukey, deve essa sua resistência, na sua maior parte, à RVi.

Analisando os resultados obtidos para número de lesões por área foliar e a porcentagem de área foliar afetada, praticamente pode-se constatar que dentre os cultivares mais resistentes destacam-se: Goiano Precoce, Jalo Precoce, Novo Jalo, IAC-Carioca e Cerro Azul, enquanto 
TABELA 11: Porcentagern* de área foliar de feijoeiro afetada por isolados de Alternaria spp.

\section{Cultivares}

\section{Isolados}

\begin{tabular}{|c|c|c|c|c|c|c|c|c|c|c|c|c|}
\hline & 1 & 3 & 4 & 5 & 7 & 8 & 9 & 10 & 11 & 2 & 6 & $\mathbf{M}$ \\
\hline Carioca & 8,6 & 0 & 4,2 & 12,5 & 9.2 & 12,4 & 5,8 & 2,7 & 3,0 & 0,4 & 0 & $4,3 \mathrm{a}^{* *}$ \\
\hline IAPAR 44 & 12,1 & 0 & 7,0 & 5,5 & 9.1 & 11,8 & 6,2 & 3,1 & 2,0 & 0 & 0 & $4,1 \mathrm{ab}$ \\
\hline Rosinha & 9,0 & 0 & 8,1 & 13,9 & 3.4 & 13,5 & 5,3 & 0,4 & 1,4 & 0,1 & 0 & $3,7 \mathrm{abc}$ \\
\hline Aporé & 9,6 & 0 & 10,0 & 6,1 & 4.4 & 17,4 & 4,2 & 0,3 & 1,6 & 0,3 & 0 & $3,6 \mathrm{abc}$ \\
\hline Roxo-90 & 3,9 & 0 & 6,8 & 4,2 & 7.0 & 21,1 & 7,6 & 1,2 & 2,4 & 0,1 & 0 & $3,6 \mathrm{abc}$ \\
\hline MD-821 & 1,7 & 0 & 5,9 & 3,2 & 8.7 & 15,3 & 7,1 & 1,5 & 5,0 & 0,2 & 0 & $3,4 \mathrm{abcd}$ \\
\hline IAPAR 57 & 6,2 & 0 & 4,8 & 1,6 & 9.6 & 8,5 & 3,2 & 0,8 & 9,6 & 0,2 & 0 & 3,1 abcd \\
\hline R. Tibagi & 7,1 & 0 & 4,8 & 0,5 & 3.8 & 15,6 & 7,2 & 1,1 & 3,8 & 0,1 & 0 & 3,0 bcde \\
\hline IAPAR 14 & 3,9 & 0 & 1,8 & 5,1 & 6.1 & 13,7 & 2,4 & 0,8 & 3,3 & 0,3 & 0 & 2,6 cdef \\
\hline C. Azul & 2,2 & 0 & 2,8 & 1,6 & 7.6 & 15,3 & 1,5 & 1,4 & 3,7 & 0,2 & 0 & $2,4 \mathrm{def}$ \\
\hline IAC-Car. & 2,1 & 0 & 2,3 & 1,0 & 1.5 & 8,5 & 5,5 & 2,6 & 4,1 & 0,1 & 0 & 2,0 ef \\
\hline Novo Jalo & 0 & 0 & 9,8 & 0,2 & 0.3 & 12,8 & 1,8 & 0 & 11,2 & 0 & 0 & $1,9 \mathrm{fg}$ \\
\hline Jalo Prec. & 0 & 0 & 8,1 & 2,3 & 0.4 & 14,4 & 2,5 & 0 & 1,8 & 0,6 & 0 & $1,7 \mathrm{fg}$ \\
\hline Goia. Prec. & 0 & 0 & 1,4 & 1,6 & 0.2 & 10,9 & 2,0 & 0 & 2,2 & 0 & 0 & $1,1 \mathrm{~g}$ \\
\hline \multirow[t]{2}{*}{$\mathrm{M}$} & 3,9 & 0 & 5,2 & 3,5 & 4,4 & 13,5 & 4,2 & 1,0 & 3,6 & 0,2 & 0 & \\
\hline & $\mathrm{C}$ & $\mathrm{E}$ & $\mathrm{B}$ & $\mathrm{C}$ & $\mathrm{BC}$ & A & $\mathrm{BC}$ & $\mathrm{D}$ & $\mathrm{C}$ & $\mathrm{E}$ & $\mathrm{E}$ & \\
\hline
\end{tabular}

* Média de 4 repetições

* Médias seguidas pela mesma letra ( maiúscula entre isolados e,minúsculas entre cultivares) não diferem entre si ao nível de 5\% de probabilidade, pelo teste de Tukey (DMS entre isolados=0,26; DMS entre cultivares $=0,30 ; C V=24 \%$ ). 

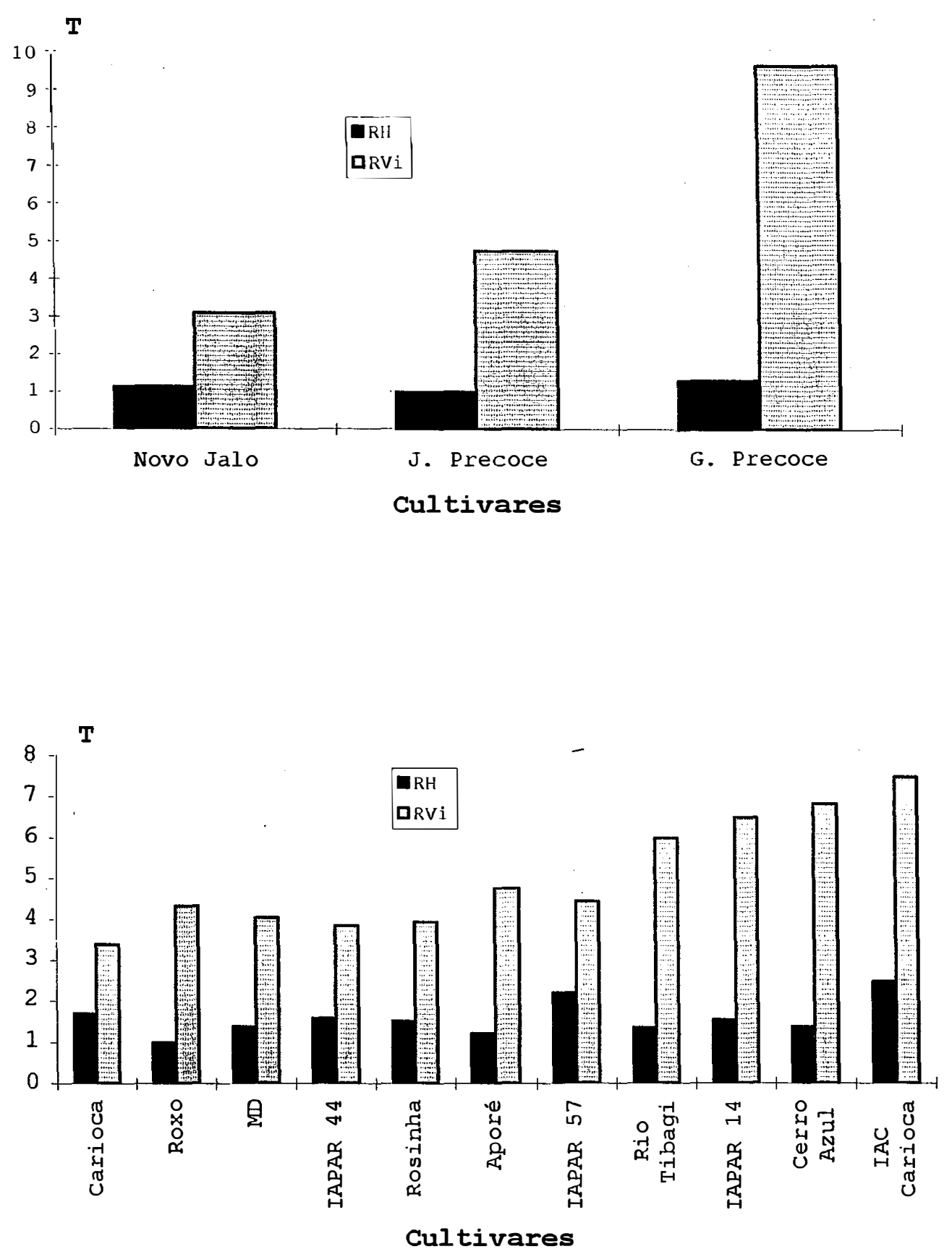

FIGURA 14: Quantificação de resistência horizontal e vertical incompleta em cultivares de feijoeiro para o parâmetro porcentagem de área foliar afetada. 
que Carioca, IAPAR 44, Rosinha e Aporé estão entre os mais suscetíveis. Estes resultados encontram apoio na literatura pois, já em 1973, Gonzáles (1973) constatou, em Costa Rica, que cultivares do grupo negro (Porrilo, Jamapa, S $182 \mathrm{~N}$ e Mex-27 N) foram suscetiveis à Alternaria sp. No Brásil, Queiroz (1991) observou que Jalo foi o mais resistente e Rosinha o mais suscetível à doença mancha de Alternária; Issa e Oliveira (1985) constataram a suscetibilidade de Carioca, Carioca-80 e de um conjunto de variedades em cruzamento para obtenção de resistência horizontal, denominado "RH pretos". Jalinho estava entre os mais resistentes à mancha de Alternária, em estudo'realizado por Castro et al.(1991); Oliveira et al. (1991) observaram que Carióca Comum foi mais suscetível à doença que Carioca SH. Dentre os cultivares que se mostraram mais resistentes deve-se chamar a atenção para aquele que apresenta maior quantidade de RH, IAC-Carioca, que é mais estável e, portanto, de grande interesse para se utilizar em programas de melhoramento. Outros materiais também possuem uma quantidade significativa de $\mathrm{RH}$, podendo ser utilizados : Goiano Precoce, IAPAR 14 e 57, MD-821, Carioca e Rosinha.

Novos cultivares têm sido lançados com resistência a Alternaria spp., graças a esforços da pesquisa, a exemplo 
do IAC-Una e IAC-Maravilha, ambos do grupo preto, pelo Instituto Agronômico, no estado de São Paulo, e do IAPAR 57, grupo diversos, pelo Instituto Agronômico do Paraná. Para recomendação regional no estado de São Paulo, foram testados os cultivares Carioca Comum, IAC-Carioca, IAPAR 14, IAPAR 31, IAPAR 44, Aysó, Aeté 3, Jalo, Pintado, Emgopa Ouro, IPA 6 e Rosinha (Oliveira et al., 1994).

Sabe-se que apenas mais recentemente os pesquisadores vêm se preocupando com a doença mancha de Alternária na avaliação dos materiais. Dentre os cultivares que estavam sendo testados em 1994, muitos são bastante suscetíveis à doença, tais como Carioca Comum, IAPAR 44 e Rosinha, enquanto que outros apresentam boa resistência, Como . I IAC-Carioca e Jalo.

o trabalho de melhoramento deve ser contínuo, e novas fontes de resistência devem ser incluídas em materiais que são resistentes a uma série de doenças, mas suscetíveis a doenças que vêm aumentando de incidência e severidade em lavouras de feijoeiro. 


\subsection{Patogenicidade dos diferentes isolados de Alternaria spp.}

No experimento de inoculação em casa-de-vegetação, verificou-se, através dos parâmetros número de lesões e porcentagem de área foliar afetada, a diferença de patogenicidade que existe entre os isolados de Alternaria spp. testados.

Segundo o parâmetro número de lesões (Tabela 10), o isolado mais patogênico, para a média dos cultivares, foi o isolado 8 , seguido pelos isolados 9, 11, 4, 7, 5, 1, 10 e 2; os isolados 3 e 6 não foram considerados patogênicos para nenhum cultivar. Os dados de porcentagem de área foliar afetada (Tabela 11) confirmam a maior patogenicidade do isolado 8. Houve uma certa alteração na ordem entre os outros isolados, em relação ao parâmetro número de lesões, ficando em ordem decrescente: 4, 7, 9, 1, 11, 5, 10, e 2 . Essa alteração parece indicar que alguns isolados podem não produzir muitas lesões, mas o tamanho destas são maiores que as produzidas por outros isolados, resultando em uma área foliar afetada maior. No caso do isolado 11, pode-se justificar o fato de afetar a área foliar em menor proporção que os outros, apesar de ser bastante patogênico, segundo o parâmetro número de lesões, por ter sido avaliado 
antecipadamente, não havendo tempo para que as lesões se expandissem.

A diferença de patogenicidade não é constatada apenas entre as espécies, mas também entre isolados da mesma espécie. No presente estudo os isolados 1 e 3 são considerados pertencentes a Alternaria cichorii, sendo que o primeiro mostrou-se patogênico e o segundo não. Do mesmo modo, para $A$. carthami e $A$. alternata, houve diferença de patogenicidade para os isolados.

O fato de haver diferença de patogenicidade entre os isolados e da interação isolados $x$ cultivares ter sido significativa, indica que nos trabalhos de seleção de cultivares para resistência, há necessidade de se considerar que um material resistente a um isolado não será necessariamente resistente aos outros isolados. Assim, o cultivar IAC-Carioca foi o mais resistente ao isolado 8; entretanto, quando o isolado utilizado foi o 9, o mais resistente foi Cerro Azul. Fica, então, caracterizado que os isolados apresentam diferentes níveis de virulência (Vanderplank, 1978) . 
Pelo teste de Tukey verifica-se que houve diferença estatística, entre os tratamentos, quanto a incidência dos isolados sobre as sementes e quanto à porcentagem de plântulas infectadas por estes, porém não houve diferença em relação à emergência. Pode-se constatar que praticamente não houve correlação entre esses parâmetros, pois os isolados de Alternaria alternata, que apresentaram quase que $100 \%$ de incidência sobre as sementes, praticamente não afetaram a emergência das plântulas nem causaram lesão nos cotilédones. Do mesmo modo, entre os isolados de $A$. carthami, como por exemplo o 7 que apresentou alta incidência sobre as sementes, mas baixo número de plântulas infectadas, ao contrário dos isolados 8 e 9 que não apresentaram incidência sobre as sementes, porém causaram alto índice de plântulas infectadas. Este resultado pode ser explicado pelo fato que estes isolados mostravam crescimento micelial no teste de sanidade, mas não houve esporulação, não sendo, então, anotadas estas sementes. Este fato sugere a necessidade de se aperfeiçoar o teste de sanidade de sementes de feijão, já que há necessidade de se quantificar as sementes portadoras do patógeno, mesmo que este não esteja formando as estruturas de propagação.

Os isolados mais patogênicos foram, em ordem decrescente, $11,9,1,4,8$ e 5, sendo que este resultado é 
semelhante àquele obtido no teste de patogenicidade, porém com algumas alterações na ordem.

Com relação à germinação em laboratório (Tabela 13), houve diferença entre os tratamentos; os isolados 4, 5, 8 e 11 causaram queda na germinação das sementes, diferindo estatisticamente da testemunha, corroborando, parcialmente, com os resultados obtidos por Gomes \& Dhingra (1983), em que sementes de feijão vagem com alta infecção de Alternaria alternata, geralmente não germinam. Este resultado contrastante entre germinação e emergência pode ter ocorrido, provavelmente, pelo fato que no primeiro teste a umidade é muito mais elevada e constante do que no teste de emergência, favorecendo o desenvolvimento do patógeno em questão.

Os dados de plântulas infectadas (P.N.I., P.A.I. e P.N.I. + P.A.I.), obtidos no teste do rolo de papel (Tabela 11), confirmam os resultados obtidos em casa-de-vegetação, de que a maioria desses isolados é transmitida para a planta. 
TABELA 13:Dados obtidos no teste de germinação de sementes de feijão inoculadas artificialmente com isolados de Alternaria spp.

\begin{tabular}{lcccc}
\hline Isolados & \% Germinação & \% P. A. I*. & \% P. N. I.* & \% PAI + PNI \\
\hline 1 & $80^{* *}$ abc & $7 \mathrm{bc}$ & $12 \mathrm{a}$ & $19 \mathrm{~b}$ \\
3 & $86 \mathrm{a}$ & $3 \mathrm{~cd}$ & $1 \mathrm{def}$ & $4 \mathrm{~cd}$ \\
4 & $67 \mathrm{~d}$ & $22 \mathrm{a}$ & $8 \mathrm{abc}$ & $30 \mathrm{a}$ \\
5 & $76 \mathrm{bcd}$ & $14 \mathrm{ab}$ & $5 \mathrm{bc}$ & $19 \mathrm{~b}$ \\
7 & $85 \mathrm{ab}$ & $6 \mathrm{bc}$ & $3 \mathrm{~cd}$ & $9 \mathrm{c}$ \\
8 & $76 \mathrm{bcd}$ & $13 \mathrm{ab}$ & $10 \mathrm{ab}$ & $23 \mathrm{ab}$ \\
9 & $84 \mathrm{ab}$ & $9 \mathrm{bc}$ & $10 \mathrm{ab}$ & $19 \mathrm{~b}$ \\
10 & $87 \mathrm{a}$ & $1 \mathrm{de}$ & $3 \mathrm{de}$ & $4 \mathrm{de}$ \\
11 & $72 \mathrm{~cd}$ & $15 \mathrm{ab}$ & $9 \mathrm{ab}$ & $24 \mathrm{ab}$ \\
2 & $86 \mathrm{a}$ & $1 \mathrm{de}$ & $0 \mathrm{f}$ & $1 \mathrm{de}$ \\
6 & $84 \mathrm{ab}$ & $3 \mathrm{~cd}$ & $0 \mathrm{f}$ & $3 \mathrm{bcd}$ \\
Testemunha $*$ & $85 \mathrm{ab}$ & $0 \mathrm{e}$ & $0 \mathrm{f}$ & $0 \mathrm{f}$ \\
\hline CV & $4,4 \%$ & $23,0 \%$ & $23,8 \%$ & $13,5 \%$ \\
\hline DMS 5\% & 7,0 & 8,1 & 6,2 & 6,7 \\
\hline
\end{tabular}

* Testemunha-Sementes não inoculadas, PAI-plântulas anormais infectadas, PNI-plântulas normais infectadas.

** Média de 400 sementes

Médias seguidas pela mesma letra não diferem entre si ao nível de 5\% de probabilidade, pelo teste de Tukey.

Os dados de plântulas infectadas, tanto no teste' de germinação quanto no de emergência, que se mostraram bastante semelhantes, foi calculado sobre o número de sementes utilizadas no teste. Para se obter a porcentagem de transmissão, deve-se fazer o cálculo considerando a incidência do fungo sobre a semente. Desse modo tem-se, por exemplo, para $\circ$ isolado $1,58 \%$ de incidência (Tabela 12) e 19\% de plântulas infectadas (Tabela 13), significando $31 \%$ de transmissão. 
Os resultados estão de acordo com aqueles encontrados por Rolim et al. (1990); os autores constataram o efeito negativo de Alternaria sp. na qualidade fisiológica das sementes de feijão e sua transmissibilidade da semente para plântula .

Apesar de ter havido efeito negativo de alguns isolados sobre a germinação em laboratório, não se observou esse efeito em casa-de-vegetação, pois não houve diferença estatística entre eles quanto à emergência. Este fato indica que a principal importância do inóculo de espécies de Alternaria, em sementes de feijão, consiste na transmissão da doença para áreas de cultivo. Esse inóculo é considerado bastante importante porque, além de poder introduzir a doença em área isenta, pode aumentar esse inóculo em áreas onde a doença já ocorra, ampliando seu potencial de dano. 


\section{CONCLUSÕES}

Analisando os resultados obtidos neste trabalho, pode-se concluir que:

- A mancha de Alternária do feijoeiro é causada por, pelo menos, duas espécies de Alternaria, semelhantes morfologicamente a: A. cichorii e A. carthami, sendo a última mais frequente;

- Os isolados de Alternaria do feijoeiro variam em patogenicidade e existem diferentes niveis de virulência entre isolados de $A$. carthami;

- Os cultivares testados apresentaram diferentes níveis de resistência, não havendo qualquer um que fosse completamente resistente a todos isolados e sendo os mais resistentes Goiano Precoce, Jalo Precoce, Novo Jalo, IACCarioca e Cerro Azul;

- o cultivar de feijão' que apresentou maior resistência horizontal a $A$. carthami foi IAC-Carioca, que 
também ficou entre os melhores quanto à resistência vertical incompleta, junto com Cerro Azul e Goiano Precoce;

- Os agentes causais da mancha de Alternária do feijoeiro são transmitidos através das sementes, podendo afetar a germinação, mas não a emergência. 


\section{REFERÊNCIAS BIBLIOGRÁFICAS}

ABAWI, G.S.; CROSIER, D. C. ; COBB, A.C. Pod-fleking of snap bean caused by Alternaria alternata. Plant Disease Reporter, v.61, n,11, p.901-5, 1977.

ALFENAS, A. C. Aplicações de eletroforese de proteínas e isoenzimas em fitopatologia. In: ENCONTRO SOBRE APLICAÇÃO DE ELETROFORESE NA AGROPECUÁRIA, 3., Nova Odessa, 1991. Nova Odessa: Instituto de Zootecnia, 1991. p.14-29.

ALFENAS, A. C. ; BROMMONSCHENKEL, S. H. Eletroforese de proteínas e isoenzimas na taxonomia e genética de fungos fitopatogênicos. In: CONGRESSO BRASILEIRO DE FITOPATOLOGIA, 22., Recife, 1989. Fitopatologia Brasileira, v.14, n.2, p.108-9, 1989.

$\mathrm{BACH}$, E. E. Utilização da eletroforese no estudo de alterações enzimáticas na interação planta-patógeno. In: ENCONTRO SOBRE APLICAÇÕES DA ELETROFORESE NA AGROPECUARIA, 1., Nova Odessa, 1989,. Nova Odessa: Instituto de Zootecnia, 1989. p.1-4. 
BACH, E. E. Comparação morfológica, patogência, serológica e eletroforética de Exserohilum turcicum (PASS) Leonard \& SUGGS. isolado de milho, sorgo e capim massambará. Piracicaba, 1991. 137 p. Dissertação (Mestrado) Escola Superior de Agricultura "Luiz de Queiroz", Universidade de São Paulo.

BACH, E. E. ; KIMATI, H. Curso teórico prático de eletroforese. Piracicaba, Escola Superior de Agricultura "Luiz de Queiroz"/ USP - Depto. de Fitopatologia, 1993. $33 \mathrm{p}$.

BRASIL. Ministério de Agricultura. Secretaria Nacional de Defesa Agropecuária. Regras para análise de sementes. Brasília, 1992. 365 p.

BULisAnI, E. A.; ALMEIDA, L. D'A. de ; ROSTOM, A.J. A cultura do feijoeiro no estado de São Paulo. In: BULISANI, E. A., coord. Feijão: fatores de produção e qualidade. Campinas: Cargill, 1987. p.29-88.

CAFATI, K. C. Reação de variedades de feijoeiro a Xanthomonas phaseoli (E.F.Sm.) Dows. e Xanthomonas phaseoli var. fuscans (Burk.) Starr \& Burk. Piracicaba, 1971. 59p. Dissertação (Mestrado) - Escola Superior de Agricultura "Luiz de Queiroz",Universidade de São Paulo.

CASTRO, H. A.; KRUGNER, T. L. ; BERGAMIN FILHO, A. Especialização fisiológica no sistema Eucalyptus grandis W. Hill ex Maiden - Puccinia psidii Winter. Ciência e Prática, v.9, n.1, p.80-92, jun./jul. 1985. 
CASTRO, J. L. Problemas fitossanitários do feijoeiro no estado de São Paulo: cultura das águas e da seca. In: SEMINÁRIOS SOBRE PRAGAS E DOENÇAS DO FEIJOEIRO, 3., Piracicaba, 1988. Anais. Piracicaba: Fundação de Estudos Agrários "Luiz de Queiroz", 1988. p.71-89.

CAStRO, J. L.; ITO, M. F.; DUDIENAS, C. ; BULISANI, E. A. Avaliação de cultivares de feijoeiro quanto à incidência de doenças, em condições de campo. In: SEMINÁRIO SOBRE PRAGAS E DOENÇAS DO FEIJOEIRO, 3., Piracicaba, 1988. Anais. Piracicaba: Fundação de Estudos Agrários "Luiz de Queiroz", 1988. p.5.

CASTRO, J. L.; ITO, M. F.; DUDIENAS, C. Avaliação de cultivares de feijoeiro quanto à incidência de doenças, em condições de campo. In: SEMINÁRIO SOBRE PRAGAS E DOENÇAS DO FEIJOEIRO, 4., Campinas, 1991. Anais. Campinas: Instituto Biológico,.1991. p.7.

CASTRO, J. L.; ITO, M. F. ; DUdienAs, C. Avaliação de genótipos de feijoeiro quanto à resistência às doenças fúngicas da parte aérea em condições de campo. In: SEMINÁRIO SOBRE PRAGAS, DOENÇAS E PLANTAS DANINHAS DO FEIJOEIRO, 5., 1994, Piracicaba. Anais, Piracicaba: Fundação de Estudos Agrários "Luiz de Queiroz", 1994. p. 8 .

CHARCHAR, M. J. A.; NASSER, L. C. B. ; GOMES, A. C. Fungos associados às sementes de feijão e trigo produzidas nas áreas irrigadas do Distrito Federal. In: CONGRESSO BRASILEIRO DE FITOPATOLOGIA, 21., Brasília, 1988. Resumo. Brasília, v.13, n.2, 1988. p.110. 
DALLA PRIA, M. ; BERGAMIN FILHO, A. Avaliação de diferentes meios de cultura na esporulação de Colletotrichum lindemuthianum, Isariopsis griseola e Alternaria sp. In: CONGRESSO PAULISTA DE FITOPATOLOGIA, 18. Piracicaba, 1995. Resumos. Surma Phytophatologica, v 21, n.1, p. 124, mar. 1995.

DIAZ POLANCO, C. ; CASANOVA, J. R. Las enfermedades fungosas mas importantes de la caraota (Phaseolus vulgaris L.) en la zona central de Venezuela. Agronomia Tropical, v.16, p.129-39, 1966.

ELLIOT, J. A. Taxonomix characters of the genera Alternaria and Macrosporium. American Journal Botany, v.4, p.439-76. 1917.

ELLIS, M. B. Dematiaceous Hyphomycetes. Kew: Commonwealth Mycological Institute, 1971. 608 p.

ELLIS, M. B. More Dematiaceous Hyphomycetes. Commonwealth Mycological Institute, Kew, Surrey, 1976. 507 p.

FANCELLI, A. L. Situação da cultura do feijão no estado de São Paulo. In: SEMINÁRIO SOBRE PRAGAS E DOENÇAS DO FEIJOEIRO, 3, Piracicaba, 1988. Anais. Piracicaba: Fundação de Estudos AGRÁRIOS "Luiz de Queiroz", 1988. $17-21$. 
FANCELLI, M. I. Comparação patogênica, cultural, serológica e eletroforética entre isolados de Alternaria solani do tomate e da batata e variabilidade patogênica de Alternaria solani f. sp. lycopersici N.F. Piracicaba, 1991. 80 p. Tese (Doutorado)-Escola Superior de Agricultura "Luiz de Queiroz", Universidade de São Paulo.

FURLAN, S. H. ; MENTEN, J. O. M. Efeito de regiões e épocas de produção na qualidade de sementes de feijoeiro no estado de São Paulo. Fitopatologia Brasileira, v.14, n.3/4, p.200-5. 1989 .

GODOY, C. V.; IAMAUTI, M. T.; DALLA PRIA, M.; CARNEIRO, S. M. T. P. G.; AMORIM, L. ; BERGAMIN FILHO, A. Diagramatic scale for bean diseases: development and validation. zeitschrift für Pflanzenkrankheiten und Pflanzenschutz. 1997 (no Prelo).

GOMES, J. L. L. ; DHINGRA, O. D. Alternaria alternata, a serious pathogen of white colored snap bean (Phaseolus vulgaris L.) seeds. Fitopatologia Brasileira, v.8, p.173-7. 1983.

GONZÁLES, L. C. Mancha foliar del frijol (Phaseolus vulgaris L.) causada por Alternaria sp. em Costa Rica. Turrialba, v.23, p.238-39. 1973.

GOULART, A. C. P. Doenças do feijoeiro na região norte de Minas Gerais. Fitopatologia Brasileira, v.13, n.3, p.203-32. 1988 . 
HALL, R. Compendium of bean diseases. St. Paul, American Phytopathological Society, 1991. 73 p.

INSTITUTO AGRONÔMICO DO PARANÁ. IAPAR-20: cultivares para o Paraná. Londrina, 1992. 140 p.

ISSA, E. ; OLIVEIRA, D.. A. Resistência de variedades de feijão Phaseolus vulgaris L., do estado de São Paulo a algumas enfermidades. In: SEMINÁRIO SOBRE PRAGAS E DOENÇAS DO FEIJOEIRO, 2., Campinas, 1985. Resumos. Campinas: Instituto Agronômico, 1985. p.36.

ISSA, E.; RAMOS, R. S. Queima de Alternaria: novo problema para a cultura do feijoeiro. In: SEMINÁRIOS SOBRE PRAGA E DOENÇAS DO FEIJOEIRO, 2. Campinas, 1985. Resumos. Campinas: Instituto Agronômico, 1985. p.18.

IAMAUTI, M. T. Avaliação de danos causados por Uromyces appendiculatus no feijoeiro. Piracicaba, 1995. 81 p. Tese (Doutorado) - Escola Superior de Agricultura "Luiz de Queiroz", Universidade de São Paulo.

ITO, M. F.; DUDIENAS, C. ; CASTRO, J. L. Nova espécie de Alternaria em feijoeiro. In: CONGRESSO PAULISTA DE FITOPATOLOGIA, 12., Araras, 1989. Resumos. Jaguariúna, 1989. p.36.

JVO, P. S. ; STOTAKY, G. Eletrophoretic analysis of isozymes from seeds of Pinus abces and Pseudotsuga. Canadian Journal Botany, v.51, p.2201-5, 1973. 
KIMATI, H. Doenças do feijoeiro. In: GALLI, F., ed., Manual de fitopatologia. 2. ed. São Paulo: Ceres, 1980. v.2, cap.19, p.297-318.

LASCA, C. C. Estudos sobre a flora fúngica de sementes de feijão (Phaseolus vulgaris L.) . Biológico, v.46, p.125 134,1978 .

LUCCA FILHO, O. A. Metodologia dos testes de sanidade de sementes. In: SOAVE, J.; WETZEL, M. M. V. da S., ed. Patologia de sementes. Campinas: Fundação Cargill, 1987. cap.10, p.276-98.

MARIOT, E. J. Ecofisiologia do feijoeiro. In: INSTITUTO AGRONÔMICO DO PARANÁ. O feijão no Paraná. Londrina, 1989. p.25-41. (IAPAR. Circular, 63).

MENTEN, J. O. M. Sanidade, germinação e vigor de sementes de feijão (Phaseolus vulgaris L.). Summa Phytopathologica, v.4, n.2/4, p.105-10, 1978.

MENTEN, J. O. M. Prejuízos causados por patógenos às sementes. In: MENTEN, J. O. M. ed. Patógenos em sementes: detecção, danos e controle químico. São Paulo: Ciba Agro, 1995. p.115-36.

MENEZES, J. R. Controle integrado de doenças em culturas irrigadas por pivô central. In: CONGRESSO BRASILEIRO DE FITOPATOLOGIA, Ilhéus, 1995 • Fitopatologia Brasileira, v.20, p.207-8, 1995. Suplemento. 
MENEZES, J. R.; MOHAN, S. K.; BIANCHINI, A. ; SOUZA, G. L. de. Qualidade sanitária de sementes de feijão (Phaseolus vulgaris L.) no estado do Paraná. Fitopatologia Brasileira, v.6, n.3, p.497-508, 1981.

MOHAN, S. K.; MENEZES, J. R. ; BIANCHINI, A. Doenças e seu controle. In: Cultura do feijão no estado do Paraná. Londrina: , 1980. p. 47-53. (IAPAR. Circular, 18) .

NEERGAARD, P. Seed Pathology. London: The Mac Millan Press, 1979. v.1, $837 \mathrm{p}$.

NUNES JR., J. ; MENTEN, J. O.M. Levantamento de fungos associados às sementes de feijão (Phaseolus vulgaris L.) no estado de Santa Catarina. In: CONGRESSO PAULISTA DE FITOPATOLOGIA, 8., Jaboticabal, 1985 . Suma Phytophatologica, v.11, n.1/2, jan./jun., p.7 1985.

OLIVEIRA, S. H. F.; BARROS, B. C.; CASTRO, J. L.; AUGUSTI, J. N.; AMARAL, H. M. ; SEBASTIANI, J. C. Reação de cultivares de feijão a doenças da parte aérea e podridões radiculares em diferentes municípios de São Paulo. In: SEMINÁRIO SOBRE PRAGAS E DOENÇAS DO FEIJOEIRO, 4., Campinas. Anais. Campinas: 1991. p.5.

OLIVEIRA, S. H. F. ; CASTRO, J. L. Eficiência de fungicidas no controle da mancha de Alternária e ferrugem do feijoeiro. In: SEMINÁRIO SOBRE PRAGAS E DOENÇAS DO FEIJOEIRO, 4., Campinas, 1991. Anais. Campinas: 1991. p. 24 . 
OLIVEIRA, S. H. F.; BARROS, B. C.; CASTRO, J. L. ; OLIVEIRA, D. A. Resposta dos cultivares Carioca Comum e Carioca SH à época de aplicação de clorotalonil e acetato de trifenil estanho, utilizados para controle de doenças do feijoeiro. In: SEMINÁRIO SOBRE PRAGAS E DOENÇAS DO FEIJOEIRO, 4., Campinas. Anais. Campinas: 1991. p.19.

OLIVEIRA, S. H. F.; WUTKE, E. B.; SANNAZZARO, A. M. Comportamento de cultivares de feijoeiro quanto à sanidade e produtividade. In: SEMINÁRIO SOBRE PRAGAS E DOENÇAS DO FEIJOEIRO, 5., Piracicaba. Anais. Piracicaba: 1994. p. 75-82.

OLIVEIRA, M. Z. A. ; MELLO, S. C. M. Fungos associados a sementes de feijão no estado da Bahia. In: CONGRESSO BRASILEIRO DE FITOPATOLOGIA, 21. , Salvador, 1988. Resumos. 1988. p.150.

PAtrício, F. R. A.; ORTOLANI, D. B. ; GOMES, R. B. R. Sanidade de sementes de feijão no estado de São Paulo. In: SEMINÁRIO SOBRE PRAGAS E DOENÇAS DO FEIJOEIRO, 4., Campinas, 1991. Anais. Campinas: 1991. p.17.

PETRUNAK, D. M.; CHRIST, B. J. Isozyme varability in Alternaria solani and $A$. alternata. Phytopathology 82: 1343-7. 1992 .

POMPEU, A. S. Melhoramento do feijoeiro (Phaseolus vulgaris L.). In: BULISANI, E. A., coord. Feijão: fatores de produção e qualidade. Campinas: Fundação Cargill, 1982. cap.1, p.1-28. 
POUND, G. S. Effect of air temperature on incidence and development of the early blight disease of tomato. Phytopathology, v.41, p.127-35, 1951.

QUEIROZ, M. F. Etiologia da mancha de Alternária e reação de genótipos de feijoeiro à doença. Viçosa, 1991. 45 p. Dissertação (Mestrado) - Universidade Federal de Viçosa.

RICHARDSON, M. J. An annotated list of sed-borne diseases. Surrey: Commonwealth Mycological Institute, 1979. 320 p.

RICHARDSON, M. J. Supplement 2 to An annotated list of seed-borne diseases (Third Edition). Surrey: Commonwealth Mycological Institute, 1983. $109 \mathrm{p}$.

RODRIGUES, P. C. Bioestatística. Universidade Federal Fluminense. EDUF-Editora Universitária. PROED Niterói, 1976. 227p.

ROLIM, P. R.; CENTURION, M. A. P.C. ; MENTEN, J. O. M. Alternaria sp. em feijoeiro (Phaseolus vulgaris L.): incidência na semente, tipos morfológicos, patogenicidade e transmissibilidade de diferentes isolados. Sumna Phytopathologica, v.16, n.2, p.130-9, 1990.

ROTEM, J. The genus Alternaria. St. Paul: APS Press, 1994. $326 \mathrm{p}$.

RUSSEL, P. E. ; BROWN, L. Alternaria alternata on Phaseolus vulgaris. Plant Pathology, v 26, n.1, p.47, 1977. 
SAAD, S. \& HAGEDORN, D. J. Symptomatology and epidemiology of Alternaria leaf spot of bean, Phaseolus vulgaris. Phytopathology, v.59, n.2, p.150-3, 1969.

SAAD, S. ; HAGEDORN, D. J. Growth and nutrition of an Alternaria pathogenic to snapbeans. Phytopathology, v.60. p.903-6, 1970 .

SANTOS, A. F. dos; ATHAYDE, J. J.; PACOVA, B. E. V. ; VARGAS, A. A. T. Severidade e prevalência de patógenos do feijoeiro no estado do Espírito Santo, 1981/82. Fitopatologia Brasileira, v.9, n.22, p.221-6, 1984.

SARTORATO, A. ; RAVA, C. A. Mancha de Alternaria. In: SARTORATO, A.; RAVA, C. A. eds. Principais doenças do feijoeiro. Brasilia: EMBRAPA, 1994. p.85-94 (EMBRAPACNPAF. Documentos, 50).

SCHWARTZ, H. F. ; GALVEZ, G. E, eds. Problemas de producción de frijol: enfermedades, insectos, limitaciones edáficas y climáticas de Phaseolus vulgaris. Cali, 1980. cap. 8, p.129-298: Diversos patógenos fúngicos.

SHANDS, H.; VIEIRA, C. ; ZAWMEYER, W. J. Observations on dry bean diseases in Brasil. Plant Disease Reporter, $v$. 48, p. 784-787. 1964 .

SIMMONS, E. G. Typification of Alternaria, Stemphylium and Ulocladium. Mycologia, v.59, p.67-91, 1967. 
SWANK, G. Alternaria leaf spot and dieback of snap bean a new disease in Central Florida. Plant Disease Reporter, v.37, n.7, p.330-2, 1951.

VAKALOUNAKIS, D. J. ; CHRISTIAS, C. Light intensity, temperature and conidial morphology in Alternaria cichorii. British of Mycological Society, v.85, n.3, p.425-30, 1985.

VANDERPLANK, J.E. Disease resistance in plants. New York: Academic Press, 1968. 206p.

VANDERPLANK, J. E. Genetic and molecular basis of plant pathogenesis. New York, 1978. 167p.

VIEIRA, C. Doenças e pragas do feijoeiro. Viçosa, UFV, Impr. Univ., 1983. $231 \mathrm{p}$.

ZAUMEYER, W. J. ; THOMAS, H. R. A monographic study of bean diseases and methods for their control.USDA, 1957. 255p. (USDA. Techinical Bulletin, 868). 